University of South Carolina

Scholar Commons

\title{
The Role of Mannosyl-phosphoryl-dihydropolyisoprenol in the Synthesis of Mammalian Glycoproteins
}

\author{
John W. Baynes \\ University of South Carolina - Columbia, john.baynes@sc.edu
}

An-Fei Hsu

Edward C. Heath

Follow this and additional works at: https://scholarcommons.sc.edu/chem_facpub

Part of the Chemistry Commons

\section{Publication Info}

Published in Journal of Biological Chemistry, Volume 248, Issue 16, 1973, pages 5693-5704.

This research was originally published in the Journal of Biological Chemisty. Baynes JW, Hsu A, Heath EC. The Role of Mannosyl-phosphoryl-dihydropolyisoprenol in the Synthesis of Mammalian Glycoproteins. Journal of Biological Chemistry. 1973; 248:5603-5704. (C) the American Society for Biochemistry and Molecular Biology. 


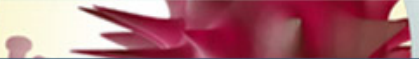

$j b c$

The Journal of

Biological Chemistry

\section{AFFINITY SITES}

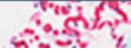

ARTICLE:

The Role of

Mannosyl-phosphoryl-dihydropolyisopreno

$l$ in the Synthesis of Mammalian

Glycoproteins

John W. Baynes, An-Fei Hsu and Edward C.

Heath

J. Biol. Chem. 1973, 248:5693-5704.

Access the most updated version of this article at http://www.jbc.org/content/248/16/5693

Find articles, minireviews, Reflections and Classics on similar topics on the JBC Affinity Sites.

Alerts:

- When this article is cited

- When a correction for this article is posted

Click here to choose from all of JBC's e-mail alerts

This article cites 0 references, 0 of which can be accessed free at http://www.jbc.org/content/248/16/5693.full.html\#ref-list-1 


\title{
The Role of Mannosyl-phosphoryl-dihydropolyisoprenol in the Synthesis of Mammalian Glycoproteins*
}

(Received for publication, March 21, 1973)

\author{
John W. Baynes, $\ddagger$ An-Fei Hsu, and Edward C. Heath $\S$ \\ From the Department of Physiological Chemistry, The Johns IIopkins University School of Medicine, \\ Baltimore, Maryland 21205, and the Department of Biochemistry, University of Pittsburgh School of Medicine, \\ Pittsburgh, Pennsylvania 15261
}

\section{SUMMARY}

A mouse myeloma tumor was used as a model system to study the biochemical steps involved in the incorporation of mannose into glycoproteins. This tumor, MOPC-46B, synthesizes a $\kappa$-type immunoglobulin light chain ( $K-46)$ which is a glycoprotein with a single oligosaccharide side chain containing mannose as one of its constituent sugars.

MOPC-46B microsomal preparations contain enzymes which transfer mannose from the sugar nucleotide, GDPmannose, to endogenous lipid and protein acceptors. Formation of the mannolipid proceeds by the reversible transfer of mannose from GDP-mannose to an endogenous phospholipid. The mannolipid was purified and characterized by chemical methods and mass spectrometry as a mannosyl-monophosphoryl-dihydropolyisoprenol, containing at least 18 isoprene units, one of which is saturated.

The mannolipid was implicated as an intermediate in the in vitro mannosylation of endogenous protein acceptors by three kinds of experiments. (a) Incorporation of $\left[{ }^{44} \mathrm{C}\right] \mathrm{man}-$ nose into protein was observed after the initial substrate, GDP-mannose, had been destroyed by sugar nucleotide hydrolases associated with the microsomal preparations. The continued increase in radioactivity in the protein fraction occurred concomitantly with a loss of radioactivity from the mannolipid fraction. (b) Incorporation of $\left[{ }^{14} \mathrm{C}\right]$ mannose into both lipid and protein was inhibited by EDTA added at zero time. However, addition of EDTA after mannolipid synthesis had occurred resulted in cessation of mannolipid formation but continued incorporation of mannose into protein to an extent proportional to the amount of mannolipid originally formed. The increase in radioactivity in protein was again accompanied by a loss of radioactivity from the mannolipid. (c) When microsomes were pulsed briefly with GDP-[ $\left.{ }^{14} \mathrm{C}\right] \mathrm{mannose}$, which was then chased by a large excess

\footnotetext{
* This research was supported by United States Public Health Service (irants AM-08318 and AM-15684. A preliminary report of this work has been presented (1).

‡ Predoctoral Trainee, United States Public Health Service Training Grant GM-00184. A portion of the data reported in this paper is taken from a thesis submitted in partial fulfillment of the requirements for the Degree of Doctor of Philosophy at the Johns Hopkins University, Baltimore, Maryland 21218.

$\S$ To whom reprint requests and correspondence should be addressed at the University of Pittsburgh.
}

of unlabeled GDP-mannose, incorporation of $\left[{ }^{14} \mathrm{C}\right]$ mannose into lipid ceased immediately with the chase, while incorporation into protein continued afterwards to an extent proportional to the amount of mannolipid formed prior to the chase.

Evidence that the mannolipid could function as a donor of mannose residues to protein was obtained by demonstrating that microsomes catalyze the transfer of $\left[{ }^{14} \mathrm{C}\right]$ mannose from exogenously supplied mannolipid to endogenous protein acceptors. The amount of mannose transferred to protein was proportional to both microsomal protein and lipid concentrations. In addition, the amount of mannose transferred to protein from exogenous mannolipid is comparable to that incorporated from an equivalent amount of mannolipid generated endogenously from GDP-mannose.

Gel filtration profiles of the $\left[{ }^{14} \mathrm{C}\right]$ mannose-containing protein formed in this system are essentially identical regardless of whether GDP-mannose or mannolipid is used as substrate. In both cases the radioactive protein fractionates in a manner similar to authentic $\mathrm{K}-46$ ( $\mathrm{mol}$ wt 24,000 ). The mannose-containing protein formed from either GDPmannose or mannolipid was degraded sequentially by Pronase and subtilisin. The products formed from either substrate appeared to be identical and exhibited chromatographic and electrophoretic characteristics of glycopeptides.

It was concluded that mammalian microsomal preparations contain an endogenous phospholipid, characterized as a dihydropolyisoprenol-monophosphate, which serves as an acceptor of mannose from GDP-mannose, resulting in the formation of mannosyl-monophosphoryl-dihydropolyisoprenol, and that this mannolipid serves as a glycosyl donor for transfer of mannose residues to endogenous protein acceptors. The evidence indicates that the mannolipid is an essential intermediate in the in vitro transfer of mannose from GDP-mannose to protein.

The predominant type of glycoprotein in plasma contains carbohydrate linked by an $N$-glycosyl bond between a reducing terminal $N$-acetylglucosamine in the oligosaccharide and an asparagine residue in the polypeptide chain. The oligosaccharide has been divided structurally into an internal or "core," region 
containing mannose and $N$-acetylglucosamine and an external region containing galactose, fucose, sialic acid, and additional $N$-acetylglucosamine residues $(2,3)$.

The biosynthesis of the external region proceeds by addition of single sugar residues to a growing oligosaccharide side chain. The sequential addition of external $N$-acetylglucosamine, galactose, sialic acid, and fucose residues by transferases of the endoplasmic reticulum and Golgi apparatus has been accomplished using exogenous protein acceptors, generally prepared by treatment of native glycoproteins with the appropriate glycosidase(s) $(2-5)$. Investigations on the mude of addition of the mannose residues in the core region, however, have been hampered by an inability to prepare efficient exogenous acceptors by glycosidase treatments, or to find native proteins which can function as artificial acceptors. Therefore, it has become necessary to study mannosyltransferase reactions using endogenous acceptors contained in the transferase preparations (6-8). These studies are frequently complicated by the low levels of endogenous acceptors in cells and their heterogeneity with respect to both the polypeptide chains and the nature of the oligosaccharide side chains. Some of these difficulties may be minimized in a system that produces a single mannose-containing glycoprotein with one oligosaccharide side chain of defined structure. We have therefore selected a mouse myeloma tumor, MOPC-4613, as a model system to study the addition of mannose residues to glycoproteins, and to investigate specifically the possible role of lipid intermediates in this process.

The plasma cell tumor, MOPC-4613, synthesizes a $\kappa$ type immunoglobulin light chain, which is a glycoprotein (mol wt 24,000 ) with a single serum type oligosaccharide side chain attached at asparagine residue 34 in the peptide chain (9-11). The oligosaccharide contains 4 mannose residues in addition to $3 \mathrm{~N}$-acetylglucosamine, 4 galactose, 2 fucose, and 2 sialic acid residues. The synthesis of $\mathrm{K}-46^{1}$ accounts for 35 to $40 \%$ of the total protein synthesis by MOPC-46B cells in suspension in vitro, as measured by relative rates of incorporation of $\left.{ }^{3} \mathrm{H}\right]$ leucine into immunoprecipitable and total trichloroacetic acid-precipitable protein $(10,12)$. In addition, similar studies using $\left[1-^{-3} \mathrm{H}\right]$ galactose and $\left[1-{ }^{3} \mathrm{H}\right]$ mannose indicate that $\mathrm{K}-46$ represents at least $50 \%$ of the total glycoprotein synthesis by the myeloma tumor (12). Thus, the MOPC-46B tumor is highly directed for synthesis of a single species of glycoprotein containing a single type of oligosaccharide side chain.

The role of polyisoprenol phosphates as glycosyl acceptors which mediate the transfer of sugars from sugar nucleotides to polysaccharides has been clearly established in prokaryotic systems (13). The widespread occurrence of similar polyisoprenoid lipids in eukaryotic systems has led to intensive investigation of their role in the synthesis of polysaccharides in yeast and plant systems, and of glycoproteins in mammalian systcms (14). The demonstration that mammalian glycoproteins are glycosylated by membrane-associated enzymes $(2-5)$, that the acceptor glycoproteins are intimately associated with the intracellular membrane fractions $(2-8,11)$, and that these membranes contain polyisoprenol phosphate (14-16) which can function in vitro as glycosyl acceptors $(8,16)$ has stimulated a number of investigalions using various sugars ( $N$-acetylglucosamine, glucose, galactose, and mannose) and lipids (dolichols and vitamins $\mathrm{A}$ and $\mathrm{K}$ ) in order to evaluate the possible role of glycolipids in the hiosvnthesis of glycoproteins (14). Mannose-accepting lipids have

1 The abbreviations used are: $\mathrm{K}-46$, the $\gamma \mathrm{G}$-immunoglobulin $\kappa$-type light chain synthesized by the MOPC-46B mouse myeloma tumor; HAc, acetic acid; $\mathrm{NH}_{4} \mathrm{Ac}$, ammonium acetate. been detected in a number of mammalian cell types, and they have been implicated as intermediates in the transfer of mannose from GDP-mannose to glycoproteins, in general (8), and to secreted proteins, in particular (17). However, dircet eharacterization of the mannolipids and conclusive identification of trichloroacetic acid-insoluble products as glycoproteins have not been previously reported. In the present study we establish the identity of the mannolipid and the glycoprotein nature of the trichloroacetic acid-insoluble product, and demonstrate by indirect and direct methods that the mannolipid is an intermediate in the in vilro mannosylation of endogenous, microsomal protein.

EXPERIMENTAL PROCEDURE

\section{Materials}

Plasma cell tumor, MOPC-46B, was obtained from Dr. Michael Potter, National Institutes of Health, and was maintained by serial transplantation in Balb/e mice. The tumors used wcre generation numbers 71 to 92 and were used 3 to 4 weeks after subcutaneous transplantation. GDP-[ $\left.U_{-}{ }^{14} \mathrm{C}\right]$ mannose $(152 \mathrm{mCi}$ per $\mathrm{mm}$ ) and $\left[{ }^{3} \mathrm{H}\right] \mathrm{GDP}(2 \mathrm{Ci}$ per $\mathrm{mm})$ were obtained from New England Nuclear Corp. Nonradioactive sugars, nucleotides, and their derivatives, and the enzymes Pronase, subtilisin, and alkaline phosphatase were obtained from Sigma. Triton X-100 used in incubation mixtures and all reagents for radioactivity measurements were obtained from Packard Instruments. The DEAE-cellulose used was Whatman DF-52 (H. Reeve Angel and Co.). Sephadex G-50, G-150, LH-20, and LH-60 were obtained from Pharmacia Fine Chemicals, Ine. Bio-Gel P-2 and Dowex 1-X8 were obtained from Bio-Rad. Unisil activated silicic acid was obtained from Clarkson Chemical Co., Inc. Adsorbents for thin layer chromatography were purchased from E. Merck. Organic solvents used in purification of lipid were reagent grade, freshly redistilled, and contained $0.01 \%$ butylated hydroxytoluene as antioxidant.

\section{Radioactivity Measurements}

Quantitative determinations of radioactivity were obtained on a Packard liquid scintillation spectrometer, model 4322. Lipid and aqueous samples were counted in a scintillation fluid consisting of toluene:Triton X-100 (2:1) containing 5.5 g per liter of 2,5-diphenyloxazole and $125 \mathrm{mg}$ per liter of 1,4 -bis [2-(4methyl-5-phenyloxazolyl)]benzene. Particulate samples were solubilized in hydroxide of Hyamine 10X and counted in toluene containing $4.0 \mathrm{~g}$ per liter of 2,5 -diphenyloxazole and $100 \mathrm{mg}$ per liter of 1,4-bis[2-(5-phenyloxazolyl)]benzene.

\section{Analytical Methods}

Protein was determined by the method of Lowry et al. (18), as modified by Miller (19), using bovine serum albumin as standard. Lipid phosphate was determined according to l'artlett (20), as modified by Dittmer and Wells (21), and reducing sugar by the method of Park and Johnson (22).

\section{Preparation of Microsomal Fraction}

Small tumors ( 2 to $3 \mathrm{~g}$ ) were excised and washed with ice-cold homogenizing buffer $(0.05$ м Tris-maleate, $\mathrm{pH}$ 7.4, containing $0.25 \mathrm{M}$ sucrose). All subsequent procedures were carried out at $0-4^{\circ}$. Necrotic tissue was removed, and the tumor was minced and suspended in $2 \frac{1}{2}$ volumes of buffer. The suspension was homogenized with 6 to 10 strokes of a motor-driven glass-Teflon Potter-Elvehjem homogenizer. The crude homogenate was centrifuged at $10,000 \times g$ for 10 min in a Sorvall RC-213 centrifuge 
in the SS-34 rotor. The supernatant fluid was decanted, and the microsomal fraction was sedimented by centrifugation for 2 hours at $78,000 \times g$ in the Beckman No. 30 rotor. The crude microsomal pellet was resuspended in homogenizing buffer at a protein concentration of 20 to $40 \mathrm{mg}$ per $\mathrm{ml}$. Enzymatic activity for transfer of mannose from GDP-mannose to lipid was stable to freezing for several months. The activity for transfer of mannose from GDP-mannose to protein was unstable, and preparations more than 1 week old were not used for that purpose.

\section{Assay Procodures}

\section{Incorporation of Mannose into Lipid and Protein}

Standard assay mixtures were incubated in $3-\mathrm{ml}$ test tubes at room temperature in the homogenizing buffer containing 1 to 100 $\mu \mathrm{M}$ GDP- $\left[{ }^{14} \mathrm{C}\right]$ mannose $(25,000$ to $200,000 \mathrm{cpm}), 5 \mathrm{~mm} \mathrm{MnCl}_{2}$, $5 \mathrm{mM} \mathrm{MgCl}_{2}$, and 0.6 to $3 \mathrm{mg}$ of microsomal protein in a final volume of $100 \mu \mathrm{l}$; larger incubation mixtures were scaled-up proportionately. Reactions were quenched by addition of 3 volumes of a solution containing 2 parts of 1-butanol-1 part of 6 M pyri-

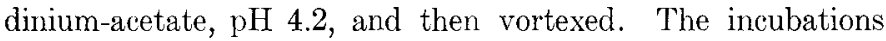
were then centrifuged for 3 to 5 min at maximum speed in the No. 809 head of an International model CL clinical centrifuge. A distinct aqueous phase and proteinaceous interface is observed from assay mixtures at low protein concentration, but at higher protein concentrations the aqueous phase is occluded within a proteinaceous pellet. The upper (organic) phase was removed nearly quantitatively with a $500-\mu \mathrm{l}$ syringe (Hamilton model No. $1750 \mathrm{~N})$. A second extraction was performed with an additional $200 \mu \mathrm{l}$ of 1 -butanol, and the combined organic extracts were washed with $500 \mu \mathrm{l}$ of $\mathrm{H}_{2} \mathrm{O}$. An aliquot of the organic phase was dried at $70^{\circ}$ in a scintillation vial and counted in toluene-Triton $\mathrm{X}-100$ scintillation fluid for estimation of mannolipid formed. The lipid-free protein pellet was dispersed and partially solubilized in $0.5 \mathrm{ml}$ of $0.5 \mathrm{M} \mathrm{NaOH}$ by sonication for $10 \mathrm{~s}$ at minimum power using the micro tip attachment of a Heat Systems-Ultrasonics model W185 sonifier-cell disruptor. Protein was reprecipitated by $2 \frac{1}{2} \mathrm{ml}$ of $10 \%$ trichloroacetic acid and collected by centrifugation. This procedure was repeated, and the pellet was finally washed with sonication in $2 \mathrm{ml}$ of $80 \%$ ethanol. The protein pellet was dispersed in $100 \mu \mathrm{l}$ of methanol, solubilized in $1 \mathrm{ml}$ of Hyamine hydroxide $10 \mathrm{X}$, and counted in $10 \mathrm{ml}$ of toluene scintillation fluid for determination of mannose incorporated into protein.

\section{Transfer of Mannose from Lipid to Protein}

Organic Solvent Extraction of Microsomal Protein-Microsomal pellets were resuspended by gentle homogenization in 3 volumes of $\mathrm{H}_{2} \mathrm{O}$, and $2-\mathrm{ml}$ aliquots were frozen in a thin shell, lyophilized, and then extracted for 1 hour at $0^{\circ}$ with $10 \mathrm{ml}$ of 1 -butanol. The delipidated protein was collected by centrifuging for $15 \mathrm{~min}$ at $10,000 \times g$, and residual butanol was removed from the pellet by lyophilization. The delipidated protein was then resuspended in homogenizing buffer so that $1 \mathrm{ml}$ corresponded to $2 \mathrm{~g}$ of original tumor. The enzymatic activity for transfer of mannose from lipid to protein was stable for several weeks upon freezing at $-20^{\circ}$.

Partial Purification of Mannolipid-[14C]Mannose-labeled lipid was extracted from mouse liver microsomes with butanol-pyridinium acetate, deacylated as described below, and applied in $\mathrm{CHCl}_{3}$ solution to a small column of DEAE-cellulose prepared in $99 \% \mathrm{CH}_{3} \mathrm{OH}$ according to Rouser (23) and equilibrated with $\mathrm{CHCl}_{3}$. The column was washed in succession with 2 volumes of $99 \% \mathrm{CH}_{3} \mathrm{OH}, 2$ volumes of $\mathrm{CHCl}_{3}$-acetic acid $(3: 1)$, and 2 volumes of $99 \% \mathrm{CH}_{3} \mathrm{OH}$. The mannolipid was then eluted with 2 volumes of $99 \% \mathrm{CH}_{3} \mathrm{OH}$ containing $0.2 \mathrm{M} \mathrm{NH}_{4} \mathrm{Ac}$, concentrated by flash evaporation, dissolved in $\mathrm{CHCl}_{3}-\mathrm{CH}_{3} \mathrm{OH}(2: 1)$, and washed by partitioning against 0.2 volumes of $\mathrm{H}_{2} \mathrm{O}$ as described by Folch (24). This lipid was stored in $\mathrm{CHCl}_{3}$ and was stable to storage at $-20^{\circ}$ for at least 2 months.

Standard Incubation-Partially purified $\left[{ }^{14} \mathrm{C}\right]$ mannolipid was added in $\mathrm{CHCl}_{3}(50$ to $100 \mu \mathrm{l})$ to $50 \mu \mathrm{l}$ of homogenizing buffer containing $1 \%$ Triton $\mathrm{X}-100,10 \mathrm{~mm} \mathrm{MnCl}$, and $10 \mathrm{~mm} \mathrm{MgCl}_{2}$. The $\mathrm{CHCl}_{3}$ phase was removed under a stream of dry nilrogen. Aliquots of fresh or delipidated microsomal protein suspensions ( 1 to $3 \mathrm{mg}$ of protein) were added with buffer to bring the final volume to $100 \mu \mathrm{l}$, and the mixture was incubated at room temperature, and quenched and processed as described above.

\section{Proteolytic Digestion of Mannose-containing Protein}

The ${ }^{14} \mathrm{C}$-labeled protein products were dispersed by sonication in $1 \mathrm{ml}$ of $10 \mathrm{M}$ urea per 20 to $30 \mathrm{mg}$ of protein, and diluted with 1 volume of $0.05 \mathrm{M}$ Tris-Cl, $\mathrm{pH} 7.8$, containing $1.5 \mathrm{~mm} \mathrm{CaCl}$. Pronase was added ( $1 \%$ of protein by weight) and digestion was carried out at $30^{\circ}$. After 18 hours the mixture was heated for 1 min at $100^{\circ}$, sonicated for $10 \mathrm{~s}$, and a second portion of Pronase was added. After an additional 18 hours, the mixture was again heated and sonicated, then adjusted to $10 \mathrm{~mm} \mathrm{EDTA}, 1 \% \mathrm{mex}$ captoethanol. Subtilisin ( $1 \%$ of protein by weight) was added, and digestion was conlinued for an additional 24 hours at $30^{\circ}$. At the end of this time solid sodium dodecyl sulfate was added to a final concentration of $2 \%$. The proteolytic digest was chromatographed on a column $(1 \times 40 \mathrm{~cm})$ of Sephadex G-150 in $1 \%$ sodium dodecyl sulfate, $1 \% 2$-mercaptocthanol, 0.1 м EITA, 0.05 m sodium phosphate, $\mathrm{pH}$ 8.0. The low molecular weight products of the proteolytic digestion were collected from the retention volume of the Sephadex G-150 column, the sodium dodecyl sulfate was removed on a column of Dowex 1-X8 (chloride form) according to Weber and Kuter (25), and urea and salts

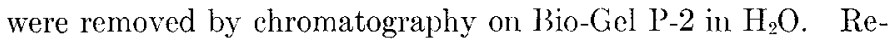
covery of a radioactivity from the Dowex 1-X8 and Bio-Gel P-2 columns was greater than $95 \%$, and essentially all of the radioactivity is recovered at the exclusion volume on the 3 io-Gel P-2 column.

\section{Purification of Bovine Liver Mannolipid}

Bovine liver $(6.5 \mathrm{~kg})$ was homogenized in a Waring Blendor in $2 \frac{1}{2}$ volumes of homogenizing medium, filtered through two layers of cheesecloth, and centrifuged at $1,500 \times g$ for $30 \mathrm{~min}$ in a Scrvall GS-3 rotor to remove whole cells and debris. The supernatant was decanted, adjusted to $\mathrm{pH} 4.9$ with 1 M acetic acid, and recentrifuged at $10,000 \times g$ for $30 \mathrm{~min}$. The pellet was resuspended to 9 liters with homogenizing medium containing $5 \mathrm{~mm} \mathrm{MgCl}_{2}$ and $5 \mathrm{~mm} \mathrm{MnCl}$, and incubated in 1 to 2 liter volumes with $4 \mu \mathrm{M}$ GDP- $\left[{ }^{44} \mathrm{C}\right]$ mannose $(1 \mu \mathrm{Ci}$ per $\mu \mathrm{m})$ for $15 \mathrm{~min}$ at room temperature and quenched by addition of 1 volume of butanol-pyridinium acetate. The organic phase was separated by centrifugation for $5 \mathrm{~min}$ at $2,000 \times g$ in an International model PR-2 refrigerated centrifuge using the No. 253 head. The organic phase was removed and the aqueous phase and iuterface were re-extracted with an additional volume of 1-butanol. The organic phases were combined, washed with an equal volume of $\mathrm{H}_{2} \mathrm{O}$, concentrated to near dryness on a rotary evaporator at $25^{\circ}$, and dissolved in 1 liter of $\mathrm{CHCl}_{3} \mathrm{CH}_{3} \mathrm{OH}(1: 1)$. The mannolipid was precipitated by addition of 5 volumes of acetone at $0^{\circ}$, and collected by centrifugation. The crude lipid was dissolved 
in 1 liter of toluene- $\mathrm{CH}_{3} \mathrm{OH}(1: 1)$, and deacylated by mild alkaline methanolysis $(0.1 \mathrm{~N} \mathrm{KOH})$ for 5 min at room temperature according to the method of White and Frerman (26); this procedure was repeated three times. The lipid was dissolved in 1 liter of $\mathrm{CHCl}_{3}$ and applied to a $400-\mathrm{ml}$ column of silicic acid. The column was washed with 2 liters of $\mathrm{CHCl}_{3}$, then the mannolipid was eluted with 2 liters of $99 \% \mathrm{CH}_{3} \mathrm{OH}$. The eluant was applied to a column of DEAE-cellulose $(4 \times 22 \mathrm{~cm})$ prepared according to Rouser (23). The column was washed in succession with 1 liter of $99 \% \mathrm{CH}_{3} \mathrm{OH}, 1$ liter of $\mathrm{CHCl}_{3}$-acetic acid (3:1), 1 liter of $99 \% \mathrm{CH}_{3} \mathrm{OH}$, and eluted with a linear gradient of 0 to $0.2 \mathrm{M} \mathrm{NH}_{4} \mathrm{Ac}(\mathrm{pH} 4)$ in $99 \% \mathrm{CH}_{3} \mathrm{OH}(27)$. The mannolipid was eluted quantitatively as a symmetrical peak of radioactivity at $0.05 \mathrm{M} \mathrm{NH}_{4} \mathrm{Ac}$. The DEAE-cellulose column was washed with $99 \% \mathrm{CH}_{3} \mathrm{OH}$ to remove salt, and the pooled Folch-washed lipid was reapplied to the same column in $\mathrm{CHCl}_{3}-\mathrm{CH}_{3} \mathrm{OH}$-concentrated $\mathrm{NH}_{4} \mathrm{OH}(40: 20: 1)$, and eluted with a linear gradient of 0 to $0.025 \mathrm{M} \mathrm{NH}_{4} \mathrm{Ac}(23)$. More than $95 \%$ of the radioactivity was eluted as a single symmetrical peak at $0.005 \mathrm{~m} \mathrm{NH}_{4} \mathrm{Ac}$. The pooled lipid was coneentrated and applicd to a column of Scphadex LH-20 $(0.8 \times 40 \mathrm{~cm})$, and eluted with $\mathrm{CHCl}_{3}-\mathrm{CH}_{3} \mathrm{OH}(1: 1)$, again yielding a single symmetrical peak of radioactivity. Preparative thin layer chromatography was performed on Silica Gel $\mathrm{G}$ in $\mathrm{CHCl}_{3}-\mathrm{CH}_{3} \mathrm{OH}-\mathrm{H}_{2} \mathrm{O}$ (12:6:1). Rhodamine $6 \mathrm{G}$ staining revealed three components with $R_{F}$ values of $0.2,0.4$, and 1.0 , respectively. All of the radioactivity was found in the band at $R_{F}$ 0.4. The mannolipid was eluted from the Silica Gel $\mathrm{G}$ with $\mathrm{CHCl}_{3}-\mathrm{CH}_{3} \mathrm{OH}-\mathrm{H}_{2} \mathrm{O}(1: 1: 0.1)$, and saponified for $30 \mathrm{~min}$ at $70^{\circ}$ under nitrogen in $60 \%$ aqueous $\mathrm{KOH}$-absolute ethannl $(1: 5$, $\mathrm{v} / \mathrm{v})$. The resulting nonradioactive lipid was extracted by addition of $\mathrm{H}_{2} \mathrm{O}$ and $n$-hexane. Analytical thin layer chromatography revealed a single component with an $R_{F}$ of 1.0 in $\mathrm{CHCl}_{3}-\mathrm{CH}_{3} \mathrm{OH}-\mathrm{H}_{2} \mathrm{O} \quad(12: 6: 1)$. On development of the chromatogram in a second dimension with $\mathrm{CHCl}_{3}$, about $90 \%$ of the iodine staining material chromatographed as a single component with an $R_{F} 0.7$.

\section{Chromatography and Electrophoresis}

Descending paper chromatography was carried out on Whatman No. 1 paper, using the following solvent systems: A, isobutyric acid-concentrated $\mathrm{NH}_{4} \mathrm{OH}-\mathrm{H}_{2} \mathrm{O}(57: 4: 39)$; and $\mathrm{B}, 1$ butanol-pyridine- $\mathrm{H}_{2} \mathrm{O}(9: 5: 4)$. Paper electrophoresis was performed on Whatman No. 3MM paper using buffer systems: C, $1 \%$ sodium borate; D, $58 \mathrm{ml}$ of $88 \%$ formic acid and $156 \mathrm{ml}$ of glacial acelic acid diluted with $\mathrm{H}_{2} \mathrm{O}$ to 2 liters ( $\mathrm{pH} 1.85$ ); and $\mathrm{E}, 25.5 \mathrm{~g}$ of sodium bartital and $3.3 \mathrm{~g}$ of barbituric acid diluted with $\mathrm{H}_{2} \mathrm{O}$ to 2 liters ( $\mathrm{pH} 8.7$ ). Unlabeled standard sugars and their derivatives were located with alkaline silver nitrate (28) after treatment of the paper with $5 \mathrm{~mm}$ periodic acid in acetone. Radioactivity was located by scanning paper strips on a Packard radiochromatogram scanner, model 7201. Quantitation of radioactivity was accomplished by cutting the paper strips into 1 -cm pieces and counting them in a vial containing $20 \%$ aqueous toluene-Triton X-100 scintillation fluid.

Thin layer chromatography was performed on Silica Gel G in solvent systems: $\mathrm{F}, \mathrm{CHCl}_{3}-\mathrm{CH}_{3} \mathrm{OH}-\mathrm{H}_{2} \mathrm{O}(12: 6: 1) ; \mathrm{G}, \mathrm{CHCl}_{3}-$ $\mathrm{CH}_{3} \mathrm{OH}-\mathrm{HOAc}-\mathrm{H}_{2} \mathrm{O}(25: 15: 4: 2)$; and $\mathrm{H}, \mathrm{CHCl}_{3}-\mathrm{CH}_{3} \mathrm{OH}_{3}$-concentrated $\mathrm{NH}_{4} \mathrm{OH}(75: 25: 4)$; and on alumina in solvent system $\mathrm{J}, \mathrm{CHCl}_{3}$-ethanol-70 mM ammonium acetate $(18: 25: 7)$ (29). Lipids were located on chromatograms by staining with either iodine vapor or rhodamine $6 \mathrm{G}$. Radioactivity was located and quantitated by scraping $1-\mathrm{cm}$ cuts into scintillation vials con-

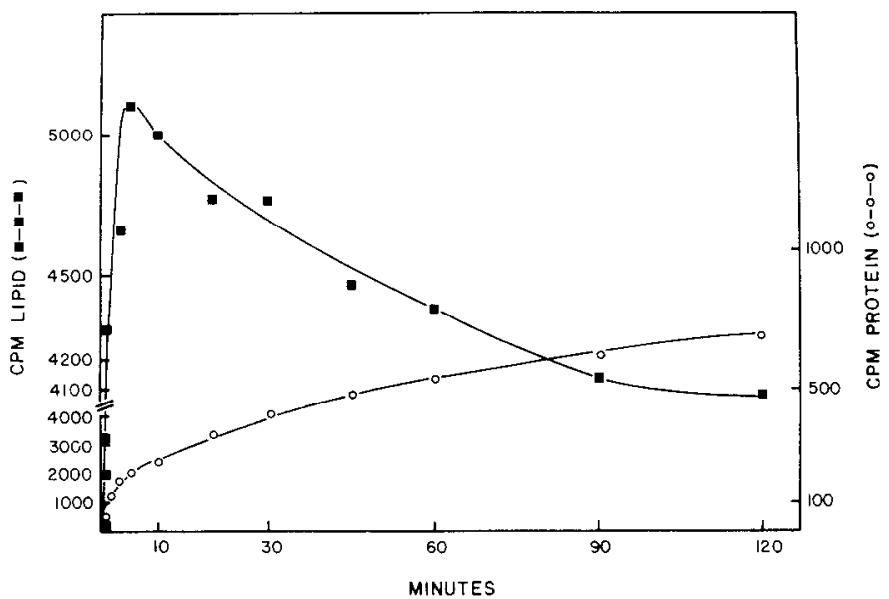

FIG. 1. Incorporation of mannose into lipid and protein. A large incubation mixture ( $2 \mathrm{ml}$ final volume) contained $4 \mu \mathrm{M}$ GDPmannose $(100,000 \mathrm{cpm})$ with $1.2 \mathrm{mg}$ of protein per $100-\mu \mathrm{l}$ aliquot. Protein and lipid were measured from $100-\mu \mathrm{I}$ aliquots as described under "Experimental Procedure." Note the expansion of the cpm lipid scale at $4000 \mathrm{cpm}$. This is done to permit comparison of the relative kinetics and extent of loss of $\left.{ }^{14} \mathrm{C}\right]$ mannose from the lipid fraction with the gain of $\left[{ }^{14} \mathrm{C}\right]$ mannose in the protein fraction.

taining $20 \%$ aqueous toluene-Triton X-100 scintillation fluid for counting.

\section{RESULTS}

\section{Synthesis and Characterization of Mannolipid}

Formation of Mannolipid--In preliminary studies it was observed that incubation of microsomal protein, isolated either from the myeloma tumor or from murine or bovine liver, with GDP- $\left[{ }^{14} \mathrm{C}\right]$ mannose resulted in an initial burst of mannose incorporation into a lipid fraction during the first $5 \mathrm{~min}$, accompanied by a decreased rate and extent of mannose incorporation in protein over a 2 -hour period (Fig. 1). Further studies revealed that incorporation into lipid is linear for about 5 min at $100 \mu \mathrm{m}$ GDP-mannose, but reaches a maximum rapidly at lower substrate concentrations because of substrate destruction presumably catalyzed by sugar nucleotide hydrolases in the microsomal preparations; the hydrolysis of GDP-mannose results in a transient production of a small amount of mannose-1-P, but after 3 min incubation in the presence of $4 \mu \mathrm{M}$ GDP-mannose only mannose is detectable in the $80 \%$ ethanol extract of the incubation mixture. The microsomal preparations are rich in both sugar nucleotide hydrolase activity and phosphatase activities, but these enzymes were neither quantitated nor further characterized.

The half-maximal rate of lipid formation is attained at about $0.7 \mu \mathrm{M}$ GDP-mannose and requires $5 \mathrm{~mm}$ divalent cation for maximal activity, but it exhibits no special preference for either $\mathrm{Mn}^{2+}$ or $\mathrm{Mg}^{2+}$. The reaction is greater than $95 \%$ inhibitcd by $2.5 \mathrm{~mm}$ EDTA. Stimulation by Triton X-100 is variable; levels up to $0.5 \%$ are not inhibitory and frequently result in up to 1 -fold stimulation of mannolipid formation. Additions of 2-mercaptoethanol, glutathione, or KF had no significant, reproducible effect on mannolipid formation.

Reversibility of Mannolipid Formation-Mannose incorporation into lipid reaches a maximum within $3 \mathrm{~min}$ at an initial concentration of $2 \mu \mathrm{M}$ GDP-mannose (Fig. 2). Addition of excess GDP at $3 \mathrm{~min}$ results in a rapid loss of $\left.{ }^{[14} \mathrm{C}\right]$ mannose from the lipid fraction; the degree of displacement is dependent on the amount of GDP added, and is completely inhibited by $10 \mathrm{~mm}$ EDTA (data 


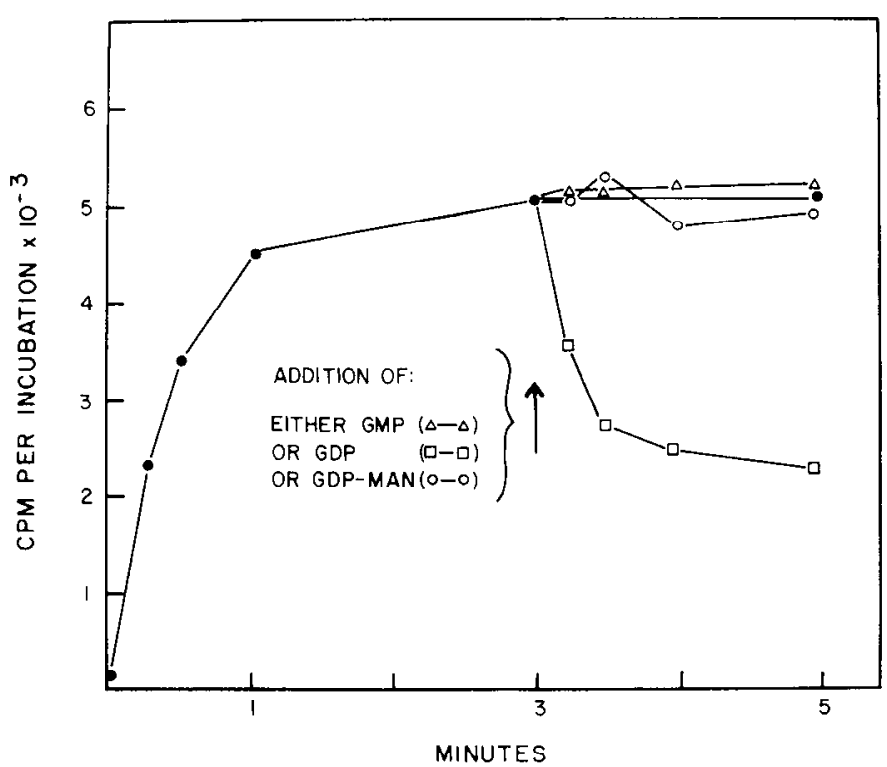

FIG. 2. Reversibility of mannolipid formation. Each point represents a separate $100-\mu \mathrm{l}$ incubation containing $1 \mathrm{mg}$ of microsomal protein and $2 \mu \mathrm{M}$ GDP-mannose $(50,000 \mathrm{cpm})$. At $3 \mathrm{~min}$, $10 \mu \mathrm{l}$ of buffer were added to the controls, and $10 \mu \mathrm{l}$ of $1 \mathrm{mM}$ GMP, GDP, or GDP-mannose were added to other incubations.

not shown). This loss is not observed upon addition of comparable quantities of either GMP or unlabeled GDP-mannose. When unlabeled GDP-mannose $(4 \mu \mathrm{M})$ was used as substrate for an incubation mixture, then followed by a 100 -fold cxecss of $\left[{ }^{3} \mathrm{H}\right] \mathrm{GDP}$ and quenched rapidly $(10 \mathrm{~s}),\left[{ }^{3} \mathrm{H}\right] \mathrm{GDP}$-mannose could be identified as a reaction product by chromatography in Solvent System A. These results are in agreement with those observed in the pig liver system (8) and indicate that the mannolipid is formed by a reversible transfer of mannose to the acceptor lipid with concomitant formation of GDP as a product, as shown below :

\section{GDP-mannose + acceptor lipid $\rightleftarrows$ mannolipid + GIPP}

According to this scheme dilution of the specific activity of the GDP-[ $\left.{ }^{14} \mathrm{C}\right]$ mannose by addition of an excess of unlabeled GDPmannose (at 3 min in Fig. 2) should also cause a dilution of radioactivity in the lipid by an exchange reaction. Richards and Hemming (8) have demonstrated this equilibrium between GDP-mannose and mannolipid in the pig liver system, but, from the results in Fig. 2, (cf. also Fig. 6), it is clear that the equilibration is not readily demonstrated in the myeloma tumor system. The failure of unlabeled GDP-mannose to dilute the lipid radioactivity in these experiments may result from the rapid destruction of GDP in these incubations, such that the reverse reaction in the proposed exchange reaction is prevented.

Specificity of Mannose Transfer to Lipid-The incorporation of $\left.{ }^{[14} \mathrm{C}\right]$ mannose into the lipid appears to be relatively specific (Fig: 3 ) in that addition of large excesses of other unlabeled sugar nucleotides does not significantly interfere with the total incorporation of mannose into lipid. GDP-glucose is the only nucleotide that inhibits incorporation of mannose into lipid, but it is possible that its degradation products, GDP and GMP, are responsible for this inhibition. The small degree of stimulation observed with the other nucleotides could result from protection of the GDP-mannose from the microsomal hydrolases. The insensitivity of the mannosyltransferase to UDP-glucose is at variance with results reported for the pig liver system (8). Glucose is, in fact, transferred from UDP-glucose to a lipid in the myeloma

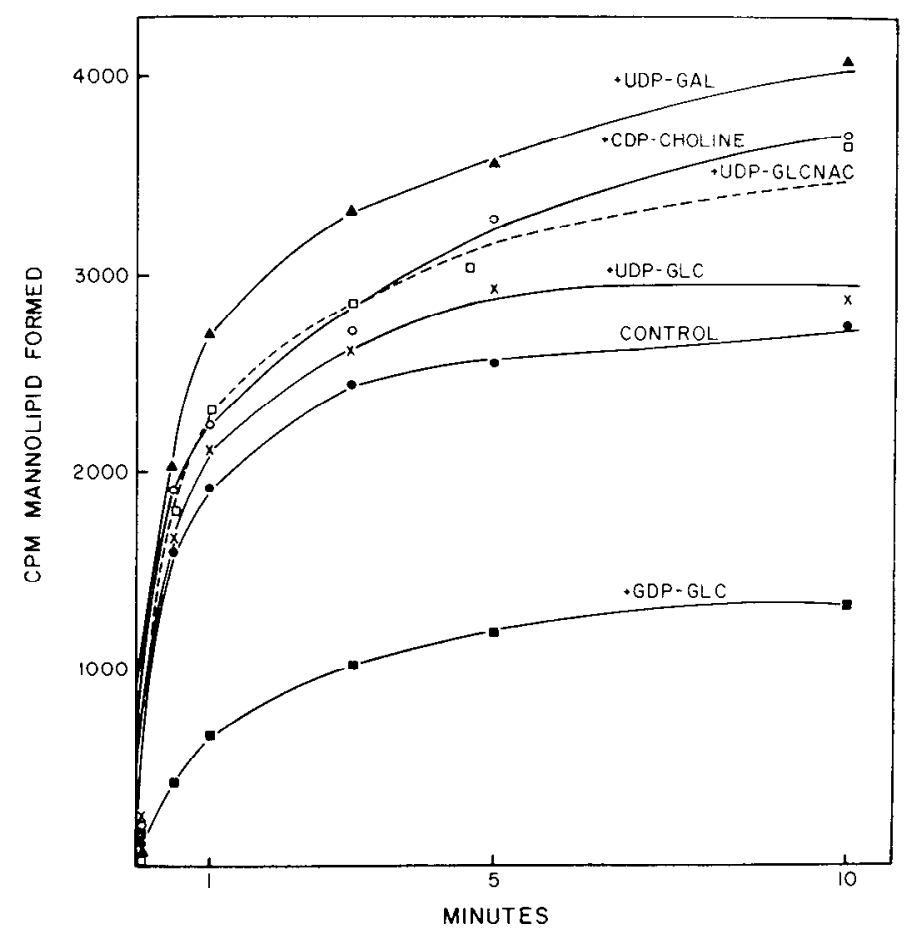

FIG. 3. Specificity of mannose transfer to endogenous acceptor lipid. Standard incubation mixtures (total volume $800 \mu \mathrm{l}$ ) containcd $4 \mu \mathrm{M}$ GDP-mannose $(100,000 \mathrm{cpm})$ and $1 \mathrm{~mm}$ competing nucleotide. Aliquots of $100 \mu \mathrm{l}$ containing $0.6 \mathrm{mg}$ of protein were withdrawn for determination of mannolipid.

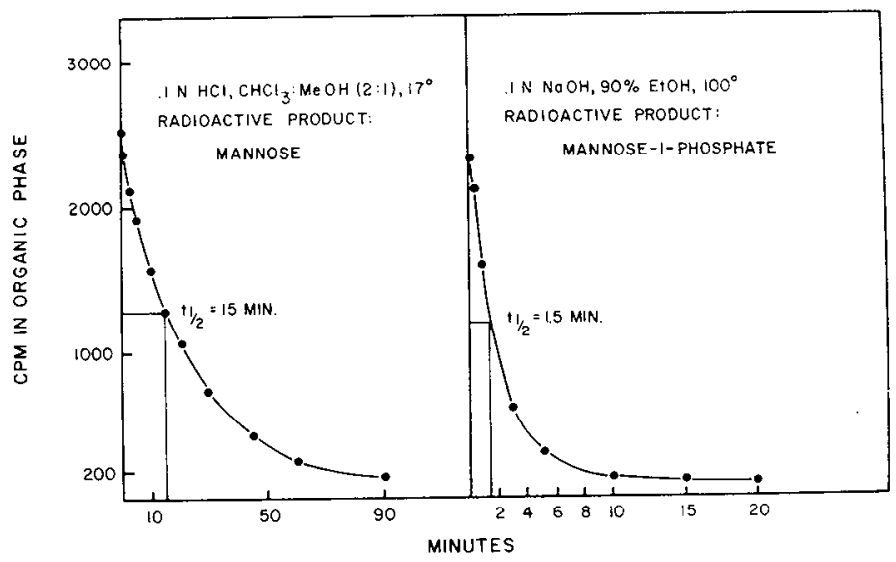

Fic. 4. Acid and base hydrolysis of crude myeloma tumor mannolipid. Acid hydrolysis : 25,000 cpm of crude lipid dissolved in $5 \mathrm{ml}$ of $\mathrm{CHCl}_{3}-\mathrm{CH}_{3} \mathrm{OH}(2: 1)$ containing $0.05 \mathrm{ml}$ of $10 \mathrm{~N} \mathrm{HCl}$, maintained at $17^{\circ}$ in a water bath. At specified times $0.5 \mathrm{ml}$ aliquots were neutralized with $0.1 \mathrm{ml}$ of $0.5 \mathrm{~N} \mathrm{NaOH}$, vortexed, and centrifuged. An aliquot of the lower (organic) phase was removed, dried, and counted in toluene-Triton X-100 scintillation fluid. Base hydrolysis : $25,000 \mathrm{cpm}$ of crude lipid dissolved in 4.5 $\mathrm{ml}$ of absolute ethanol and $0.5 \mathrm{ml}$ of $1 \mathrm{~N} \mathrm{NaOH}$, maintained at $100^{\circ}$ in boiling water bath. Aliquots of $0.5 \mathrm{ml}$ were placed in ice, neutralized with $0.05 \mathrm{ml}$ of $1 \mathrm{~N} \mathrm{HCl}$, and partitioned into two phases by addition of $0.8 \mathrm{ml}$ of $\mathrm{CHCl}_{3}$ and $0.15 \mathrm{ml}$ of $\mathrm{H}_{2} \mathrm{O}$. The lower phases were counted as above.

tumor microsomes, as reported for the pig liver system, and this lipid is indistinguishable from the mannolipid on thin layer chromatography in Solvent Systems F, G, and H. The reason for the differences in the competitive interaction between GDPmannose and UDP-glucose in the liver and myeloma tumor systems remains to be established.

Mild acid or base hydrolysis of crude lipid extracts (Fig. 4) 
resulted in quantitative release of radioactivity into the aqueous phase following Folch partitioning against $\mathrm{H}_{2} \mathrm{O}(24)$. On treatment of the $\left[{ }^{14} \mathrm{C}\right.$ mannose-labeled lipid with $0.01 \times \mathrm{HCl}$ for $2 \mathrm{~min}$ at $100^{\circ} \mathrm{in} 50 \% 1$-propanol, the radioactivity is recovered quantitatively in the aqueous phase as $\left[{ }^{14} \mathrm{C}\right]$ mannose (identified by chromatography in Solvent System B). No other radioactive compound was detectable. In $0.1 \mathrm{~N} \mathrm{HCl}$ in $\mathrm{CHCl}_{3} \mathrm{CH}_{3} \mathrm{OH}$ $(2: 1)$ at $17^{\circ}$ the mannolipid has a half-life of $15 \mathrm{~min}$, and the products in the aqueous phase were identified as mannose and methyl-mannoside (chromatography in Solvent System $\mathrm{A}$ and electrophoresis in $1 \%$ sodium borate). In $0.1 \mathrm{~N} \mathrm{NaOH}$ in $90 \%$ ethanol at $100^{\circ}$, the mannolipid has a half-life of $1.5 \mathrm{~min}$, and the product in the aqueous phase was identified as mannose-1- $\mathrm{P}$ (chromatography in Solvent System A and electrophoresis in 1\% sodium borate). Based on the kinetics of hydrolysis of the lipid in both acid and base and the nature of the water-soluble products, it was concluded that the mannose was linked by a glycoside bond to the lipid moiety through a phosphate or pyrophosphate bond.

Characterizalion of Mannolipid-The $\left[{ }^{14} \mathrm{C}\right] \mathrm{mannolipids}$ formed with either the myeloma tumor or bovine liver systems were indistinguishable and both appeared to be single species by several criteria. (a) A single band of radioactivity was located on analytical thin layer chromatography on Silica Gel G in Solvent Systems F $\left(R_{F}=0.6\right), \mathrm{G}\left(R_{F}=0.95\right)$, and $\mathrm{H}\left(R_{F}=0.35\right)$, and on alumina in Solvent System $\mathrm{J}\left(R_{F}=0.2\right)$. (b) During preparative isolation of the lipid (see "Experimental Procedure") a single peak of radioactivity was obtained from a column of DEAEcellulose eluted with a gradient of 0 to $0.2 \mathrm{M} \mathrm{NH} \mathrm{Ac}_{\mathrm{Ac}} \mathrm{pH} 4$, in $99 \% \mathrm{CH}_{3} \mathrm{OH}$ (elution at $0.05 \mathrm{M}$ salt), or a gradient of 0 to $0.025 \mathrm{M}$ $\mathrm{NH}_{4}$ Ac in $\mathrm{CHCl}_{3}-\mathrm{CH}_{3} \mathrm{OH}$-concentrated $\mathrm{NH}_{4} \mathrm{OH}(40: 10: 1$ ) (elution at $0.005 \mathrm{~m}$ salt). (c) A single peak of radioactivity was obtained on elution from Sephadex LH-20 and LH-60 in three different solvents: $\mathrm{CHCl}_{3}, 99 \% \quad \mathrm{CH}_{3} \mathrm{OH}$, and $\mathrm{CHCl}_{3}-\mathrm{CH}_{3} \mathrm{OH}$ $(1: 1)$. (d) The kinctics and extent of acid and base hydrolysis of the mannolipid in crude extracts were consistent with the existence of a single species of lipid.

In order to obtain sufficient quantity for structural studies, the mannolipid was purified from bovine liver microsomes by standard fractionation techniques (see "Experimental Procedure"), and the phosphorus to sugar ratio in the lipid was used as an index of purification (Table I). The final product, 20,000-fold purified over the crude extract, exhibited an organic phosphorus to acid-labile reducing sugar ratio of 1.2 . This product was homogeneous in terms of the distribution of radioactivity and iodine staining on thin layer chromatography on Silica Gel G in Solvent Systems F, G, and H. The discrepancy between the quantity of mannose in the lipid determined by specific radioactivity of the G.DP- $\left[{ }^{[4} \mathrm{C}\right]$ mannose and that determined by reducing sugar assay following mild acid hydrolysis probably reflects the presence of a low level of endogenous mannolipid in the microsomal preparation. In the expcriment outlincd in Table I, a $33 \%$ loss of lipid occurred in the purification when the lipid was exposed to acidic conditions during concentration of fractions from the first I)EAE-cellulose column. This was a handling error, and in subsequent isolations, the over-all recovery at the stage prior to thin layer chromatography was improved to better than $90 \%$. Recovery of the radioactive lipid from the single radioactive band obtained on thin layer chromatograms rarely exceeded $60 \%$; this loss resulted from both irreversible adsorption of the lipid to silica gel, and partial degradation of a fraction of the lipid to water-soluble forms.

The ultraviolet spectrum of the purified mannolipid $(0.1 \mathrm{~mm}$
TABLE I

Purification of bovine liver mannolipida

\begin{tabular}{|c|c|c|c|}
\hline Fraction & Mannose $^{b}$ & $\begin{array}{c}\text { Organic } \\
\text { phosphorus }\end{array}$ & $\begin{array}{l}\text { Phosphorus to } \\
\text { mannose ratio }\end{array}$ \\
\hline & umoles & umoles & \\
\hline Butanol extract....... & 1.8 & $1.4 \times 10^{5}$ & $8 \times 10^{4}$ \\
\hline Acetone precipitate. & 1.5 & $8.6 \times 10^{4}$ & $5.7 \times 10^{4}$ \\
\hline Silicic acid eluate. . & 1.5 & $1.2 \times 10^{3}$ & 800 \\
\hline DEAE-eluate. . . . . . . & 1.0 & & \\
\hline Sephadex LH-20 eluate.... & 0.8 & 15 & 19 \\
\hline Preparative thin layer & & & \\
\hline chromatography........ & $0.4(1.1)^{c}$ & 1.4 & $3.5(1.2)^{c}$ \\
\hline
\end{tabular}

"See "Experimental Procedure" for details.

${ }^{b}$ From specific activity of GDP-[ $\left.{ }^{14} \mathrm{C}\right]$ mannose ( $1 \mu \mathrm{Ci}$ per $\mu$ mole).

c Reducing sugar estimated after acid hydrolysis by the method of Park and Johnson (22).

organic phosphate in $n$-hexane using the Cary 14 recording spectrophotometer) was compared to the spectra of vitamin $\mathrm{A}$ acetate and vitamin $\mathrm{K}$ (menadione) at similar concentrations. The absorption of both the mannolipid and the free lipid (prepared by base hydrolysis) was negligible and featureless in the 300 to $400 \mathrm{~nm}$ range. There is no indication that the mannolipid from bovine liver contains a conjugated carotenoid (vitamin A) or ubiquinone (vitamin $\mathrm{K}$ ) component in its structure, thus indicaling that these polyisoprenoid lipids are not a major form of mannose-accepting lipid in bovine liver in vitro.

Analysis of the lipid by mass spectrometry after alkaline hydrolysis indicates that the lipid is a polyisoprenoid compound. The mass spectrum, illustrated in Fig. 5, reveals a characteristic pattern of triads of fragment ions separated by 68 mass units, representing random cleavage between individual isoprene units in a chain. The prominent peak in each triad has a mass/charge value of $[(n \times 68)+2]$, i.e. 2 mass units greater than the equivalent ions for undecaprenyl lipids isolated from bacterial systems $(30,31)$. The molecular ion was not visible in the mass spectrum and, thus, the precise number of isoprene units in the lipid remains to be cstablished. However, on the basis of its spectral characteristics, it was concluded that the lipid was a dihydropolyisoprenol, consisting of at least 18 isoprene units, one of which is saturated. These results suggest that the lipid is a form of dolichol (15), a C-100 $\alpha$-saturated polyisoprenol, which, as dolichol monophosphate, has been characterized as a glycosyl acceptor in liver microsomes by Leloir $(16,32)$, and Hemming (8), and their co-workers. In addition, the chemical and chromatographic properties of the mannolipid are comparable to those of synthetic dolichol-monophosphate-mannose prepared according to Behrens, Leloir et al. $(16,32)$.

\section{Role of Mannolipid in Glycosylation of Protein}

Incorporation of Mannose into Mannolipid and Protein-As shown in Figs. 1 and 2 the incorporation of mannose from CDP$\left.{ }^{[14} \mathrm{C}\right]$ mannose into mannolipid reached a plateau after approximately $5 \mathrm{~min}$ of incubation in the presence of less than $10 \mu \mathrm{M}$ GDP-mannose. The cessation of mannolipid formation could be attributed to the total destruction of GDP-mannose in the incubation mixture within the first 5 min. As illustrated in Fig. 1, however, incorporation of mannose into protein continued for at least 2 hours, concomitant with a decrease in mannolipid. During the period from 5 to $120 \mathrm{~min}$, the radioactivity in protein increased by approximately $500 \mathrm{cpm}$, while the decrease in mannolipid during the same period was approximately $1000 \mathrm{cpm}$. 
H'IG. 5. Mass spectrum of bovine liver mannolipid. Purified mannolipid ( $0.5 \mu \mathrm{M}$ organic phosphorus) was saponified as deseribed under "Experimental Procedure," and analyzed by mass spectrometry on an LKB type 9000 mass spectrometer at 70 e.v. ionization energy, using a direct probe at $250^{\circ} .^{2}$
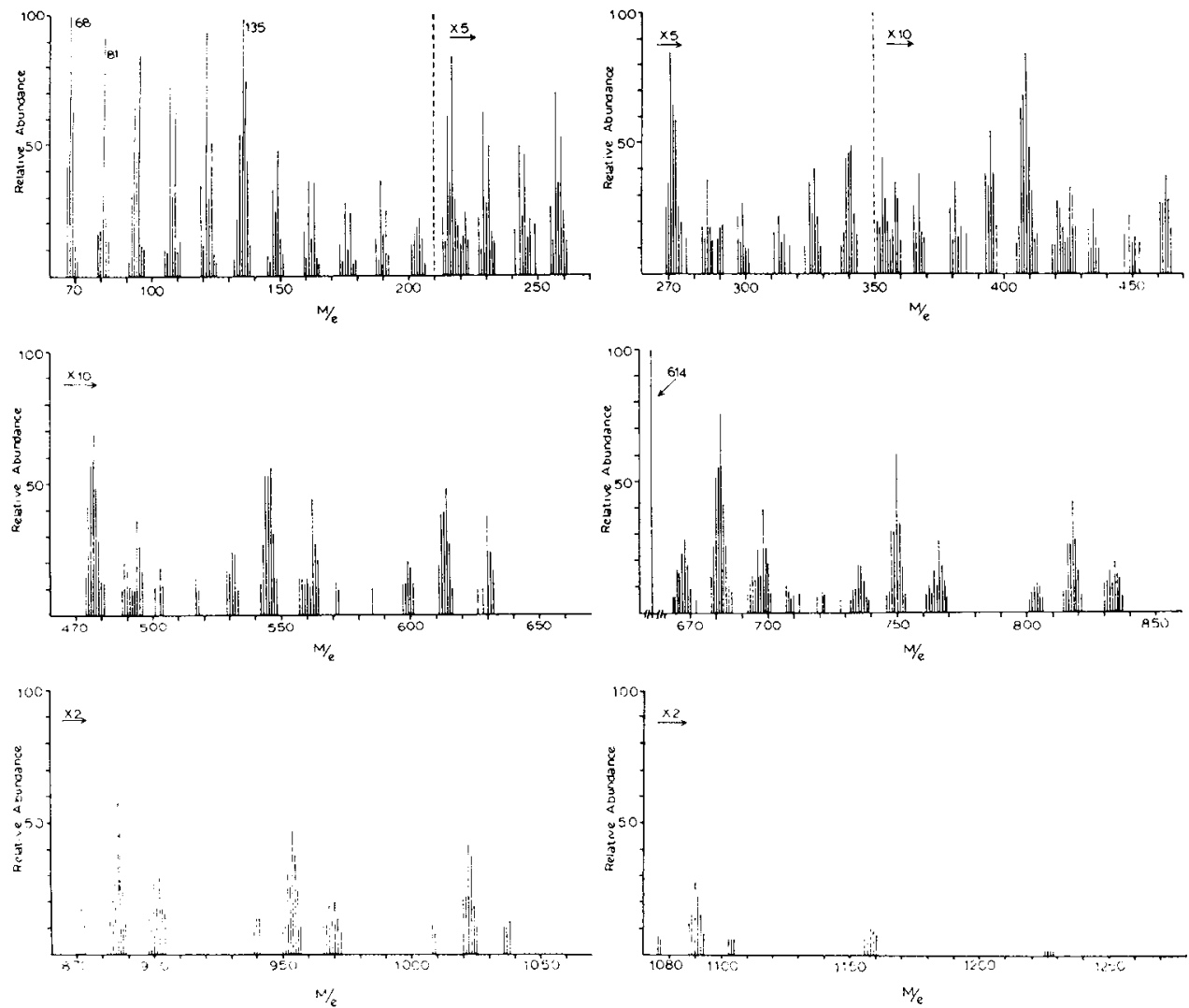

Thus, these results suggested that the mannose-containing lipid was serving as a precursor to mannose residues incorporated into the protein fraction.

In these experiments, mannolipid formation accounted for 5 to $10 \%$ of added substrate, and 0.2 to $1 \%$ of the $\left[{ }^{11} \mathrm{C}\right]$ nuannose was recovered in the protein fraction. In general, the amount of $\left[{ }^{14} \mathrm{C}\right]$ mannose incorporated into protein after 2 hours of incubation was directly proportional to the amount of mannolipid originally formed in the incubation mixture. In Figs. 6 and 7 this dependency of protein mannosylation on lipid formation is also observed. Loss of $\left[{ }^{14} \mathrm{C}\right]$ mannose from the mannolipid, however, is generally 2 - to 3 -fold in excess of the amount required for mannosylation of protein. It is apparent that some of the mannolipid is undergoing degradation to produce free mannose or mannose 1-phosphate, but another more complex product, in addition to protein, is also being formed from the mannolipid; this is discussed in more detail in the text discussion of Fig. 8.

Pulse-chase Kinetics-When the GDP-[ $\left[{ }^{14} \mathrm{C}\right]$ mannose is chased by an excess of nonradioactive substrate at times prior to the cessation in mannolipid formation (less than $3 \mathrm{~min}$ ), the subsequent incorporation of radioactivity into lipid and protein is affected differently. As illustrated in Fig. 6, addition of a 100 fold excess of GDP-mannose at 30 s results in an abrupt cessation in mannose incorporation into the lipid fraction, with an eventual resumption of incorporation at about 1/100th the original rate. Despite the effective chase in the mannolipid-forming reaction, however, incorporation of mannose into protein persists following the chase and ultimately reaches a value proportional to the amount of mannose incorporated into the mannolipid during the 30 -s pulse, i.e total incorporation into protein at $60 \mathrm{~min}$ is about $8 \%$ of mannolipid formed in each incubation mixture. From

${ }^{2}$ We are indebted to Dr. Tain Camplell of the Mass Specirometry Facility, University of Pittsburgh for conducting the mass spectral analyses.

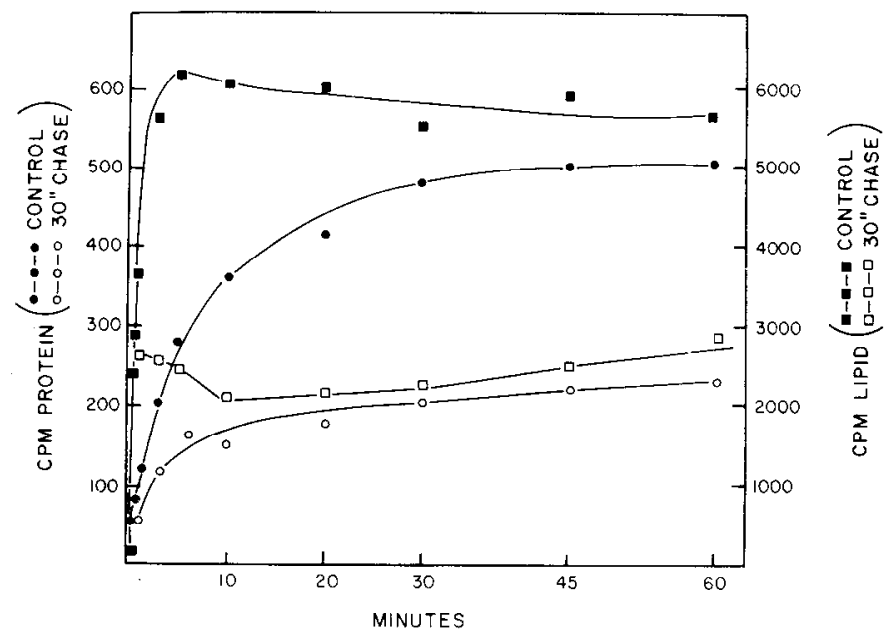

FIG. 6. Pulse-chase kinetics of mannose incorporation into lipid and protein. Two scparate incubations of 1.0 and $1.3 \mathrm{ml}$, respectively, contained $4 \mu \mathrm{m}$ GDP-mannose $(100,000 \mathrm{cpm})$ with 1.2 $\mathrm{mg}$ of protein per $100-\mu \mathrm{l}$ aliquot. To the first incubation $100 \mu \mathrm{l}$ of $10 \mathrm{~mm}$ GDP-mannose were added as a chase at $30 \mathrm{~s}$, and aliquots were withdrawn starting at 1 min. The second incubation (control) had been diluted equivalently with buffer at zero time.

these results, GDP-mannose appears to be the direct precursor for mannose incorporation into the mannolipid, but not into the protein fraction. The results are consistent with the previous evidence (Fig. 1) that the mannolipid may serve as an intermediate in the transfer of mannose from GDP-mannose to protein.

Effect of EDTA on Incorporation of Mannose into Lipid and Protein-Addition of $50 \mathrm{~mm}$ EDTA to an incubation at $5 \mathrm{~min}$, after mannolipid formation has reached a maximum, has no significant effect either on the subsequent kinetics and extent of mannose incorporation into protein or on the rate of disappear- 


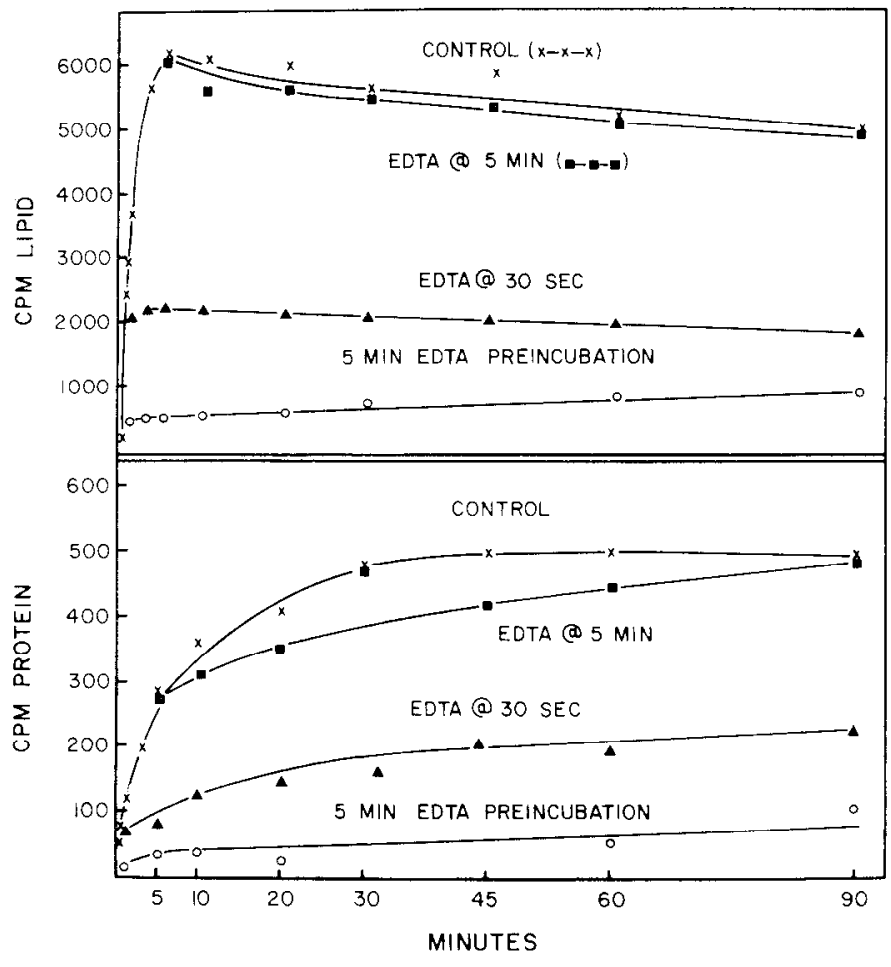

FIG. 7. Effect of EDTA on incorporation of mannose into lipid and protein. All incubations were conducted at $4 \mu \mathrm{M}$ GDPmannose $(100,000 \mathrm{cpm})$, and contained $1.2 \mathrm{mg}$ of protein per $100-\mu 1$ aliquot. Aliquots of $0.5 \mathrm{~m}$ sodium EDTA, pH 7.0, were added at -5 min (preincubation) or at $+30 \mathrm{~s}$ or +5 min respectively; GDP-mannose was added at zero time. Final EDTA concentration was $50 \mathrm{~mm}$.

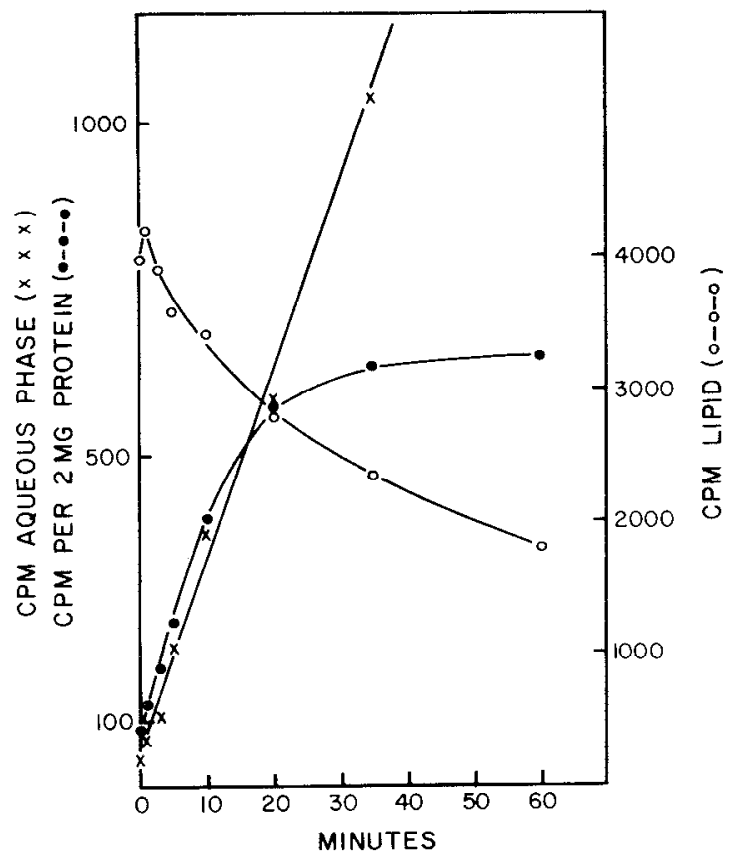

FIG. 8. Direct transfer of mannose from mannolipid to protein. A $1-\mathrm{ml}$ incubation mixture contained $20 \mathrm{mg}$ of delipidated mierosomes and $40,000 \mathrm{cpm}$ of partially purified mannolipid. Aliquots $(100 \mu l)$ were quenched with $300 \mu$ l of butanol-pyridinium acetate then diluted with $200 \mu \mathrm{l}$ of $\mathrm{H}_{2} \mathrm{O}$, and centrifuged. Distinct aqueous and organic phases were collected separately; two additional extractions were performed with $300 \mu$ of butanol-pyridinium acetate and $200 \mu \mathrm{l}$ of $\mathrm{H}_{2} \mathrm{O}$, and the aqueous and organic extracts were pooled and counted. The protein fraction was washed and counted as described under "Experimental Procedure." ance of mannose from the lipid fraction (Fig. 7, upper two curves of each frame). Preincubation with EDTA, or addition of EDTA immediately prior to addition of GDP-mannose, however, results in nearly complete inhibition of mannose incorporation into both lipid and protein (Fig. 7, lowest curve of each frame). If EDTA is added at intervals up to $5 \mathrm{~min}$ (30 $\mathrm{s}$ in Fig. 7), incorporation of mannose into lipid ceases immediately while mannose incorporation into protein continues to an extent approximately proportional to the amount of mannolipid formed prior to addition of EDTA. Even in the mixture preincubated with EDTA, the amount of $\left[{ }^{14} \mathrm{C}\right]$ mannose incorporated into protein is approximately 5 to $10 \%$ of the mannolipid formed.

Thus, by the use of $\operatorname{EDT} \Lambda$ to chelate divalent cations, it is possible to show that, of the two mannosyltransferase reactions, only the transfer to lipid is dependent on $\mathrm{Mn}^{2+}$ or $\mathrm{Mg}^{2+}$. Nevertheless, the extent of mannose incorporation into protein is indirectly sensitive to EDTA and is controlled by the extent to which mannose is incorporated into lipid. These observations are similar to those of Scher and Lennarz (33) on mannan synthesis in Micrococcus lysodiekticus, and provide further indirect evidence that the mannolipid is an intermediate in the transfer of mannose from G.DP-mannose to protein.

Direct Transfer of Mannose from Mannolipid to Protein-All attempts to demonstrate the transfer of mannose from exogenously supplied, crude mannolipid preparations to endogenous microsomal protein were unsuccessful. However, delipidation of the microsomal preparation by treatment with organic solvents and partial purification of the $\left[{ }^{14} \mathrm{C}\right]$ mannolipid used as substrate provided a system that permitted the direct utilization of the mannolipid as a mannosyl donor in the glycosylation of endogenous microsomal protein. It was later shown that delipidation of the microsomes was not necessary, but that the most critical factor was the use of purified $\left[{ }^{14} \mathrm{C}\right]$ mannolipid as substrate. This purification scheme (see "Experimental Procedure") degrades glycerophospholipids by alkaline methanolysis, and uses batch elution from DE $\Lambda$ E-cellulose with $\mathrm{CHCl}_{3}$-acetic acid $(3: 1)$ to remove neutral lipids, fatty acids, and bile salts (23). The mannolipid is then eluted with $99 \% \mathrm{CH}_{3} \mathrm{OH}$ containing $0.2 \mathrm{M} \mathrm{NH}{ }_{4} \mathrm{Ac}$.

The utilization of the purified $\left[{ }^{14} \mathrm{C}\right]$ mannolipid as substrate for the transfer of mannose residues to protein is illustrated in Fig. 8. In this incubation mixture approximately $15 \%$ of the $\left.{ }^{[14} \mathrm{C}\right]-$ mannose added as $\left[{ }^{14} \mathrm{C}\right]$ mannolipid was transferred to protein. A larger proportion of the radioactivity was recovered in the aqueous phase. When the material in the aqueous phase was collected from a second incuhation mixture quenched at $60 \mathrm{~min}$ and chromatographed on a column of $\mathrm{Bio}-\mathrm{Gel} \mathrm{P}-2$ in $\mathrm{H}_{2} \mathrm{O}, 50 \%$ of the radioactivity eluted as a sharp peak at the exclusion volume of the column (exclusion mol wt $\sim 1800$ ). The remainder eluted as a second sharp peak at the retention volume, and was identified as mannose by electrophoresis in $1 \%$ sodium borate.

When the material at the exclusion volume of the P-2 column was rechromatographed on Sephadex G-50 in $0.15 \mathrm{M} \mathrm{NaCl}$, it was eluted as a single peak of radioactivity with an apparent molecular weight of 2200 (estimated from data in Reference 34). This material migrated toward the anode upon electrophoresis in Buffer D at pH 1.85, but treatment with alkaline phosphatase converted it to a neutral compound, indieating that it was not a peptide. The composition, source, and function of this low molccular wcight compound containing mannose and phosphate are currently under study.

The extent of transfer of mannose from mannolipid to protein is dependent on several factors. $\left[{ }^{14} \mathrm{C}\right]$ Mannolipid in the crude lipid extract is totally inactive as a glycosyl donor, probably 
because of contamination by a large excess of other lipids and their degradation products. The partial purification obtained by alkaline methanolysis and DEAE-cellulose chromatography yields an active preparation, and further purification by thin layer chromatography after the DEAE-cellulose step results in only a slight increase in activity. The advantage of the additional purification step, however, is offset by the poor recovery of mannolipid from thin layer plates. Delipidation of the microsomal protein does not alter the amount of mannose transferred from mannolipid to protein during an incubation, but the transferase activity is more stable to storage following delipidation. It is possible that the transferase is sensitive to free fatty acids and lysophospholipids relcascd gradually by phospholipases in the microsomes. Since the delipidation procedure removes greater than $90 \%$ of the lipid phosphorus, the formation of these inhibitors would be decreased.

The extent of transfer of mannose from mannolipid to protein is directly proportional to both protein and lipid concentration (Fig. 9). The increasing extent of mannolipid utilization for transfer to protein with increasing protein concentration (Fig. $9 A$ ) is cxpected in a reaction dependent on endogenous acceptor. The addition of several different proteins (e.g. bovine serum albumin, ovalbumin, thyroglobulin, and ribonuclease) to incubations results in a nonspecific stimulation of incorporation of mannose into endogenous protein acceptors by the tumor microsomes. Despite the fact that ovalbumin has terminal mannose and acetylglucosamine residues (35), and thyroglobulin (36) and ribonuclease (37) have terminal mannose residues, there is no indication, by gel chromatography of the mannose-containing protein products of an incubation, that any of these proteins serves as an exogenous mannose acceptor from GDP-mannose

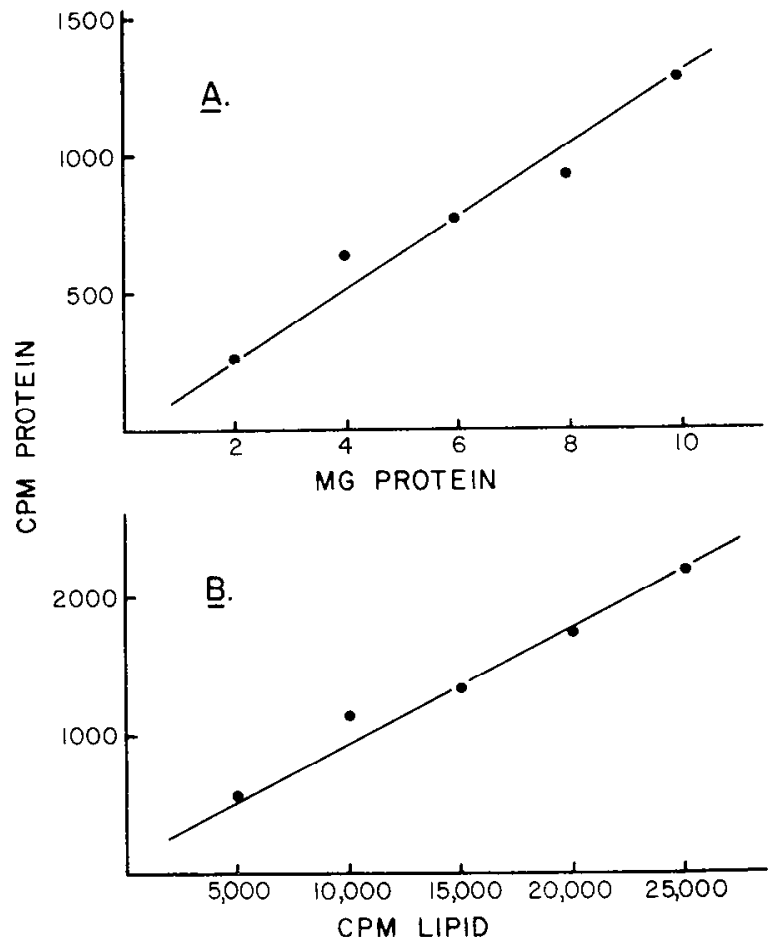

FIG. 9. Effect of protein $(A)$ and lipid $(B)$ concentration on transfer of mannose from mannolipid to protein. Standard $300-\mu l$ incubation mixtures contained increasing aliquots of delipidated protein $(A)$ or partially purified mannolipid $(B)$. In $A$, incubations contained $10,000 \mathrm{cpm}$ of lipid. In $B$, incubations contained $10 \mathrm{mg}$ of protein. Separate zero time blanks were run for each incubation. The yield of $\left[{ }^{14} \mathrm{C}\right]$ mannose-labeled protein was measured at $45 \mathrm{~min}$. or mannolipid. While there is eridence that yeast mannans are synthesized from GDP-mannose by way of a mannolipid intermediate $(38,39)$, addition of yeast mannan to incubation mixtures had no effect on the tumor system.

The fact that addition of greater amounts of exogenous lipid to an incubation results in an increased yield of [ $\left.{ }^{14} \mathrm{C}\right]$ mannoselabeled protein (Fig. 9B) probably indicates increased activity of the labile transferase at increasing, but subsaturating, levels of the mannolipid substrate. These observations are consistent with similar experiments using fresh microsomes with GDPmannose as substrate where the extent of mannose incoryoration into protein is also linearly dependent on both the protein concentration (data not shown) and the amount of mannolipid generated endogenously from GDP-mannose (Figs. 6 and 7 ).

Effect of Organic Solvent Extraction of Microsomes-Butanol or acetone (31) extraction of microsomes causes a 40 to $60 \%$ decrease in the amount of $\left[{ }^{14} \mathrm{C}\right]$ mannolipid formed from GDPmannose per $\mathrm{mg}$ of protein in an incubation mixture. There is also a proportional decrease in the amount of mannose transferred from GDP-mannose to protein. The activities for transfer of mannose to lipid and protein are not sensitive to the organic solvent extractions, however, since both activities can be restored to their original levels by supplementing the incubation mixtures with aliquots of the organic solvent extract. The restoration of activity is dependent on an acidic lipid fraction (based on DEAE-cellulose chromatography) which is stable to mild alkaline methanolysis. The active lipid is presumably the mannose acceptor lipid, dihydropolyisoprenol monophosphate. The simultaneous stimulation of mannose transfer from GDPmannose to both lipid and protein is consistent with its proposed role as a glycosyl carrier lipid. Richards and Hemming (8) have also reported the stimulatory effect of polyisoprenol phosphates on transfer of mannose from GDP-mannose to both lipid and protein in liver microsomal preparations.

Relative Efficiency of Endogenous and Exogenous Mannolipid as Mannose Donor to Protein-. The observation that crude microsomes could transfer mannose from mannolipid to protein provided a means to test quantitatively the precursor-product relationship between mannolipid and mamnosylated protein. Thus, regardless of whether GDP-[14C]mannose is used as the original substrate to generate $\left[{ }^{14} \mathrm{C}\right]$ mannolipid in situ, or a similar amount of $\left[{ }^{14} \mathrm{C}\right]$ mamnolipid is supplicd exogenously, the same amount of $\left[{ }^{14} \mathrm{C}\right]$ mannose should be incorporated into protein. The results shown in Table II establish that crude microsomes utilize either endogenously generated (from GDP-mannose) or exogenously supplied mannolipid with equal efficiency for transfer of mannose to protein. In both Experiments $A$ and 13 the percentage of transfer of mannose from endogenously generated mannolipid to protein is comparable to the percentage of transfer from exogenously supplied lipid. The presence of the large excesses of GDP-mannose $(200,000$ to $360,000 \mathrm{cpm})$ in the experiments generating endogenous mannolipid results in no mannose incorporation into protein beyond that which can be accounted for by the lipid alone. Thus, the role of GDP-mannose as a direct and immediate donor of mannose residues to protein appears to be insignificant in the mycloma microsomal system. Similar results were observed using mouse liver microsomes.

Mannolipid as Direct Donor of Mannose to Protein-Richards and Hemming (8) have reported that incubation of $\left[{ }^{14} \mathrm{C}\right] \mathrm{man}-$ nolipid with pig liver microsomes results in the formation of GDP-[14C]mannose, presumably by reaction of the mannolipid with endogenous GDP in the microsomal preparations. Thus, it is conceivable that the mannolipid is functioning as a stable 
reservoir of activated mannose residues, gradually generating GDP-mannose to serve as the actual donor of mannose to protein during the incubation. The results in Table III describe a direct experiment to verify the role of mannolipid as the immediate donor of mannose to protein.

Thus, in the presence of $50 \mathrm{~mm}$ EDTA, transfer of mannose from GDP-mannose to both lipid and protein is greatly inhibited (Table III, compare first two lines of each experiment). Less than $0.05 \%$ of the mannose is transferred to protein in either experiment in the presence of EDTA. Under the same conditions, however, exogenously added mannolipid functions as a relatively efficient donor of mannose to protein (Table III, last line of each experiment). About $2 \%$ of the mannose radio-

\section{TABLE II}

\section{Relative efficiency of endogenously formed versus exogenously added mannolipid as substrate for transfer of mannose to protein}

Each incubation contained $5 \mathrm{~mm} \mathrm{MgCl}_{2}, 5 \mathrm{~mm} \mathrm{MnCl}_{2}, 0.5 \%$ Triton X-100, and $3 \mathrm{mg}$ of protein in a total volume of $200 \mu \mathrm{l}$. Experiments A and B were performed using separate preparations of both protein and lipid. The mannolipid counts per min value in parentheses (incubations using GDP-mannose as substrate) is the amount of mannolipid formed from the GDP-mannose at 5 min (plateau).

\begin{tabular}{c|c|c|c|c}
\hline \multirow{2}{*}{ Experiment } & \multicolumn{2}{|c|}{ Substrate } & \multirow{2}{*}{$\begin{array}{c}\text { Product protein } \\
(60 \text { min) }\end{array}$} & $\begin{array}{c}\text { Percentage of } \\
\text { transfer of lipid } \\
\text { to protein }\end{array}$ \\
\cline { 2 - 3 } & GDP-mannose & Mannolipid & & \\
\cline { 3 - 4 } A & \multirow{2}{*}{200,000} & $(28,000)$ & 2,876 & 10 \\
& & 28,000 & 3,247 & 12 \\
B & \multirow{2}{*}{360,000} & $(50,800)$ & 2,799 & 5.5 \\
& & 27,000 & 1,208 & 4.5 \\
\hline
\end{tabular}

\section{TABLE III}

Effect of EDTA on mannose transfer to protein from GDP-mannose and mannolipid

Each incubation mixture contained $0.5 \%$ Triton $\mathrm{X}-100$ and 3 $\mathrm{mg}$ of protein in a final volume of $200 \mu \mathrm{l}$. Either $5 \mathrm{~mm} \mathrm{MgCl}_{2}$ and $5 \mathrm{~mm} \mathrm{MnCl}_{2}\left(\mathrm{M}^{2+}\right)$, or $50 \mathrm{~mm}$ sodium EDTA, pH 7.4 were added, as indicated. Experiments A and B were performed with different protein preparations. Reactions were quenched at $45 \mathrm{~min}$ for determination of mannose incorporated into protein. The mannolipid counts per min value in parentheses (incubations with GDP-mannose as substrate) is the amount of mannolipid determined at the 45 -min time point. Percentage of transfer to protein is based on amount of added substrate; values in parentheses are based on amount of mannolipid generated endogenously from GDP-mannose.

\begin{tabular}{|c|c|c|c|c|c|c|}
\hline \multirow{2}{*}{ Experiment } & \multicolumn{2}{|c|}{ Substrate } & \multirow{2}{*}{$\mathrm{M}^{2+}$} & \multirow{2}{*}{ EDTA } & \multirow{2}{*}{$\begin{array}{l}\text { Product } \\
\text { protein }\end{array}$} & \multirow{2}{*}{$\begin{array}{l}\text { Percentage o } \\
\text { transfer from } \\
\text { original } \\
\text { substrate to } \\
\text { protein }\end{array}$} \\
\hline & $\begin{array}{c}\text { GDP- } \\
\text { mannose }\end{array}$ & Mannolipid & & & & \\
\hline \multirow{5}{*}{ A } & \multicolumn{2}{|c|}{$c p m$} & & & $c p m$ & \\
\hline & 360,000 & $(32,700)$ & + & - & 1,214 & 0.3 \\
\hline & 360,000 & $(2,280)$ & - & + & 152 & 0.04 \\
\hline & & 45,000 & + & - & 1,930 & 4.3 \\
\hline & & 45,000 & - & + & 1,034 & 2.2 \\
\hline \multirow[t]{4}{*}{ B } & 260,000 & $(15,610)$ & + & - & 640 & 0.17 \\
\hline & 360,000 & $(2,980)$ & - & + & 25 & 0.01 \\
\hline & & 20,000 & + & - & 587 & 2.9 \\
\hline & & 20,000 & - & + & 362 & 1.8 \\
\hline
\end{tabular}

activity is transferred from mannolipid to protein, and about $80 \%$ is recovered unchanged from the incubation. Even if all of the exogenously added mannolipid substrate were converted to GDP-mannose in these incubations, this amount of GDPmannose would be inadequate to account for the protein product because of the low efficiency $(0.05 \%)$ of transfer from GDPmannose in the presence of EDTA. Thus, the mannolipid must be serving as the direct donor of mannose residues to protein and as a true intermediate in the mannosylation of glycoprotein by GDP-mannose.

A 40 to $50 \%$ inhibition of mannose transfer from lipid to protein is observed in the presence of EDTA (Table III, compare last two lines of each experiment). The reason for the effect is not clear, but it may result from differential solubility or an altered state of the mannolipid in incubation mixtures in the absence of divalent cation. This effect of EDTA is not observed in the absence of Triton X-100 ( $c f$. Fig. 7) where the lipid is presumably firmly fixed in the microsomal membrane structure.

\section{Characterization of Protein Products}

Gel Chromatography - Since fresh microsomes could use either GDP-mannose or mannolipid for mannose transfer to protein, the protein products formed from the two substrates could be compared. The radioactivity profiles of the sodium dodecyl sulfate-solubilized protein products on Sephadex G-150 (Fig. $10 \mathrm{~A}$ ) indicate that both GDP-mannose and mannolipid are transferring mannose to the same endogenous protein acceptor(s) in the myeloma tumor microsomes. In addition, the majority of the radioactivity elutes in a peak which has the same elution volume as authentic K-46, the predominant species of glycoprotein in the MOPC-46B cell. This elution pattern is different from that obtained with microsomes of the host mouse liver (Fig. $10 B$ ) which synthesizes a whole spectrum of proteins for secretion. Even in the liver, however, there is an essential identity between the radioactivity profiles of protein labeled from either GDP-mannose or mannolipid.

Proteolytic Digestion-Confirmation that mannose-labeled product which was precipitable by organic solvent (butanolpyridinium acetate), $10 \%$ trichloroacetic acid and $80 \%$ ethanol, was, in fact, a glycoprotein was obtained by demonstrating its conversion to low molecular weight material upon incubation with proteolytic enzymes (Fig. 10C). Control incubations without proteolytic enzymes showed less than $5 \%$ conversion to low molecular weight products, while proteolysis normally resulted in 50 to $100 \%$ conversion with an average value of about $70 \%$. Proteolysis was performed in $5 \mathrm{~m}$ urea, and both Pronase and subtilisin were required for efficient digestion. The protein products had been thoroughly denatured and aggregated by precipitation and extraction with organic solvent, trichloroacetic acid, and ethanol, and were not readily digestible under milder conditions of proteolysis. The undenatured mannose-containing protein in the incubation mixtures, however, was greater than $80 \%$ digestible by Pronase, subtilisin, trypsin, or pepsin but not by hyaluronidase or $\beta$-amylase, as determined by the decrease in butanol-pyridinium acetate and trichloroacetic acid-precipitable radioactivity at the end of 4 hours.

The low molecular weight products of the proteolytic digestion were subjected to electrophoresis under acidic (Buffer D) and basic (Buffer E) conditions (Fig. 11), and were shown to be zwitterionic, behaving as cations at $\mathrm{pH} 1.9$ and anions at $\mathrm{pH}$ 8.7, consistent with their characterization as glycopeptides. Within the limits of resolution of the electrophoresis, the glycopeptides from GDP-mannose and mannolipid behave identically. Follow- 


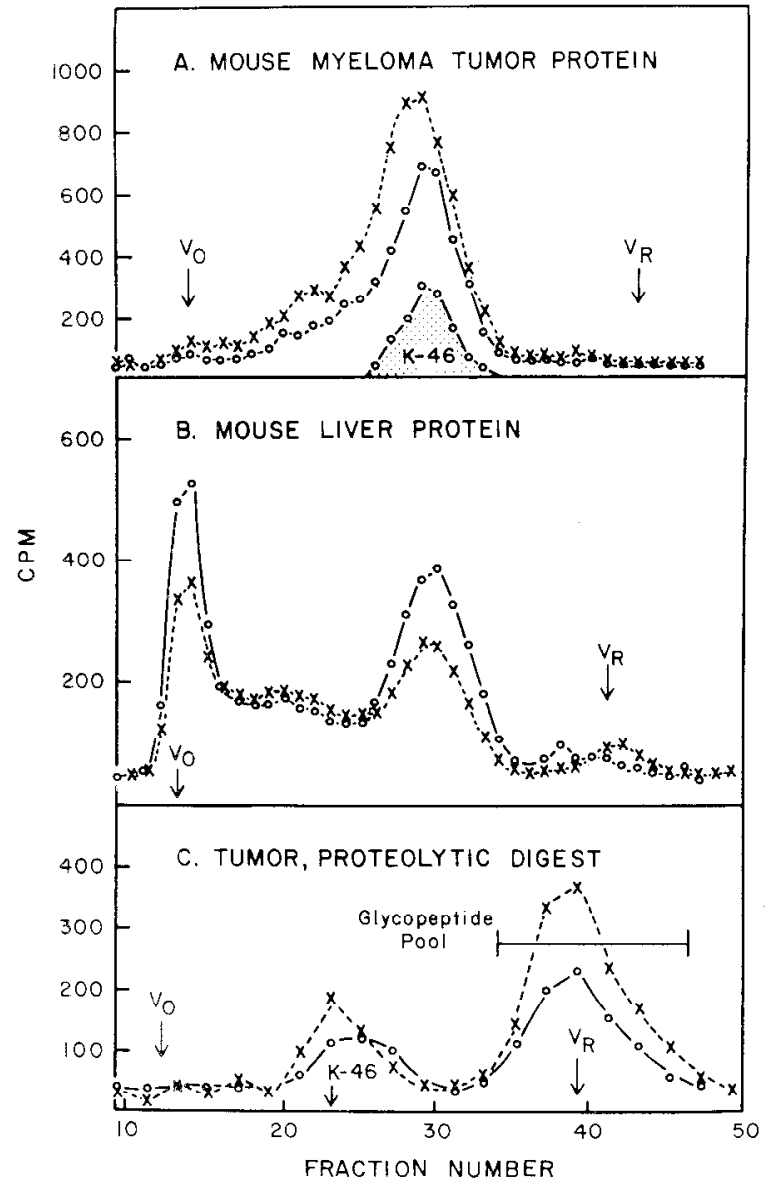

FIG. 10. Sephadex G-150 profiles of sodium dodecyl sulfate-solubilized protein from incubations using GDP-mannose $(X---X)$ or mannolipid $(\mathrm{O}-\mathrm{O})$ substrates. Protein recovered from incubations was solubilized in $2.5 \%$ sodium dodecyl sulfate, $1 \%$ mercaptoethanol, 0.1 м EDTA, 0.05 м sodium phosphate, $\mathrm{pH} 8.0$ applied to a column $(1 \times 40 \mathrm{~cm})$ of Sephadex $\mathrm{G}-150$, and eluted with the same buffer containing $1 \%$ sodium dodecyl sulfate. $A$, mannose-containing protein from incubations with mouse myeloma microsomes. The position of $\left[{ }^{3} \mathrm{H}\right] l$ leucine-labeled $\mathrm{K}-46$, prepared according to Melchers et al. (40), is shown at one-tenth scale. $B$, mannose-containing protein from incubations with mouse liver. $C$, tumor protein after proteolysis by Pronase and subtilisin (see "Experimental Procedure"). Glycopeptides were pooled (Fractions 35 to 47 ) for electrophoresis shown in Fig. 11 Final yields were $12,900 \mathrm{cpm}$ of peptide from $17,850 \mathrm{cpm}$ of protein from GDP-mannose ( $73 \%$ recovery), and $7000 \mathrm{cpm}$ of peptide from 11,700 epm of protein from mannolipid (60\% recovery).

ing acid hydrolysis of separate preparations of glycoprotein it was shown that all of the radioactivity co-chromatographed with a mannose standard on paper chromatography in Solvent System B.

\section{DISCUSSTON}

The results of the present study clearly establish that a dihydropolyisoprenol phosphate functions as a glycosyl carrier lipid in mammalian systems, mediating the transfer of mannose from GDP-mannose to protein. The experiments described in Table III establish that the mannolipid can function as a direct donor of mannose residues to protein. It is clear that mannolipid is not forming GDP-mannose in situ to serve as the glycosyl donor since, in the presence of FDTA, GDP-mannose is incffective in the glycosylation of protein. Three independent experimental approaches using GDP- $\left[{ }^{14} \mathrm{C}\right]$ mannose as initial substrate confirm the role of the mannolipid as an intermediate. (a) When the

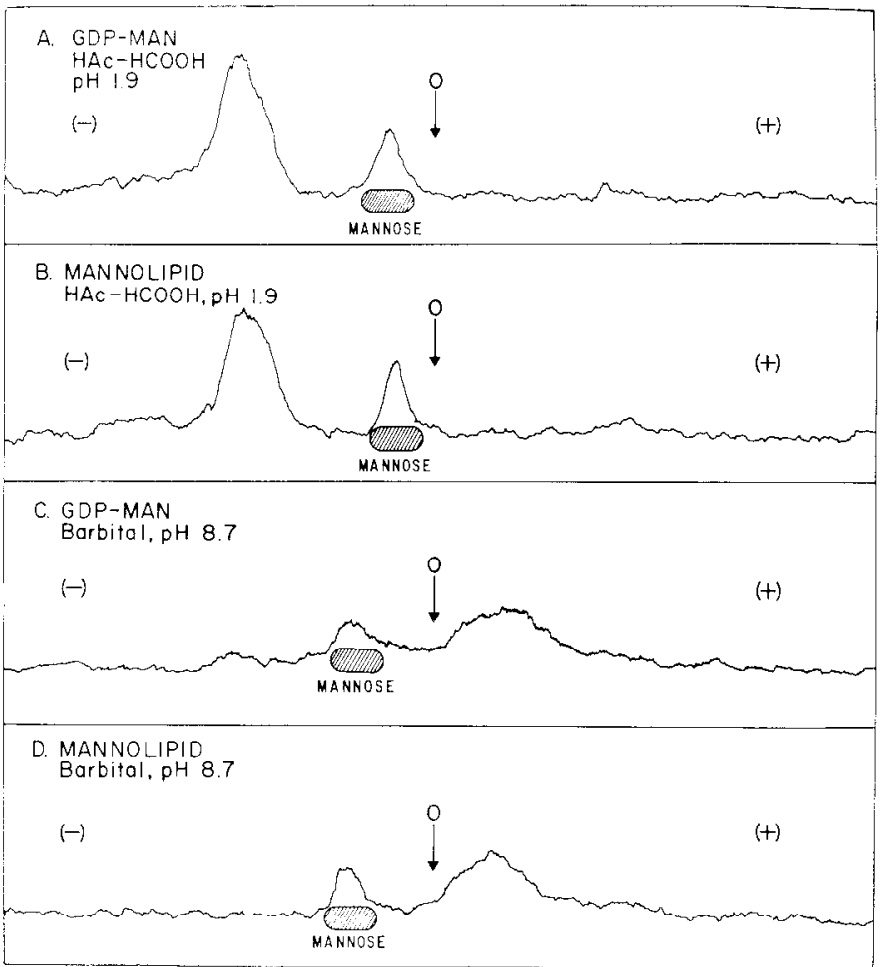

Fig. 11. Flectrophoresis of glycopeptides. The mannose containing protein from incubations of myeloma tumor micro. somes with either GDP-mannose or mannolipid were digested with Pronase and subtilisin and were processed as described under "Experimental Procedure." Electrophoresis was performed for 2 hours at 2500 volts. An unlabeled mannose standard was included in each sample to measure the migration of neutral compounds in the electroendosmotic flow of buffer.

GDP-mannose had been completely degraded in the incubation mixture (Fig. 1), incorporation of mannose into protein continued concomitant with a loss of radioactivity from the lipid fraction. (b) When GDP-[14C]mannose was chased with a large cxcess of nonradioactive substrate, incorporation of $\left[{ }^{14} \mathrm{C}\right]$ mannose into protein continued normally (Fig. 6) to an extent proportional to the amount of $\left[{ }^{14} \mathrm{C}\right]$ mannolipid formed prior to the chase. (c) As shown in Fig. 7, EDTA inhibits transfer of mannose to both lipid and protein when added at zero time, while addition at later times during the incubation resulted only in a cessation of mannolipid formation. Incorporation into protein continued afterwards to an extent proportional to the amount of mannolipid formed prior to addition of EDTA.

In experiments with the microsomal preparation from mycloma tumors, it appears that the mannolipid is an essential intermediate in mannose transfer to protein. When microsomes were incubated with either GDP-mannose or mannolipid as substrate, the gel filtration profiles of the protein products are qualitatively similar (Fig. 10). Electrophoretic comparison of the peptides produced by proteolysis of the protein products from either substrate, GDI'-mannose or mannolipid (Fig. 11), also supports the contention that both substrates are glycosylating the same or similar proteins. Moreover, it is clear from the results in Table II that the amount of mannose transferred to protein is quantitatively proportional to the amount of mannolipid available, regardless of whether the mannolipid was generated endogenously from GDP-mannose or added exogenously.

The mannosylated protein formed in tumor microsomes from either GDP-mannose or mannolipid fractionates on Sephadex $\mathrm{G}-150$ in sodium dodecyl sulfate in essentially the same relative 
position as authentic K-46 (Fig. 10A). Further studies are in progress to determine whether the acceptor protein is, in fact, related to the synthesis of $K-46$, the major natural glycoprotein product of the myelonat tumor in vivo. It can be seen, however, that the mannosylated proteins formed in mouse liver microsomes are different from those observed in the tumor system, suggesting that there is a characteristic class of proteins glycosylated in each cell type.

Only a single species of polyisoprenoid mannolipid was detected in bovine and mouse liver and in the mouse myeloma tumor. The ultraviolet and visible spectra of the purified mannolipid provided no evidence of a conjugated carotenoid (vitamin A), chromane (vitamin E), or ubiquinone (vitamin K) strue ture, nor did the mass spectrum of the lipid at probe temperatures below $250^{\circ}$ reveal fragmentation patterns attributable to these polyisoprenoid vitamins. These results do not exclude the possibilities that: (a) vitamin $\mathrm{A}(41-43), \mathrm{E}$, or $\mathrm{K}$ (44) derivatives may serve as mannose acceptors in vitro; (b) they may function as glycosyl carrier lipids in other cell types; or (c) these vitamins may be converted in vivo to a lipid which serves as a mannose acceptor. It appears, however, that the endogenous glycosyl carrier lipid participating in transfer of mannose to protein in the liver and myeloma tumor is a long chain dihydropolyisoprenol phosphate. It is not yet clear whether the same lipid or distinct members of a family of isoprenoid lipids function as carriers for different sugars, but there is strong evidence indicating that both ylucose $(16,32,45)$ and $N$-acetylglucosanine $(46-48)$ are lransferred to protein through glycolipid intermediates.

In bacterial systems the undecaprenyl lipids function in the cell envelope as glycosyl carrier lipids, intermediate in the biosynthesis and polymerization of complex carbohydrate-containing macromolecules $(13,14,27,30,31,33)$. While there is 110 direct evidence, a similar mechanism may also be operative in mammalian systems for the synthesis of the core region of the oligosaccharide side chain of plasma glycoproteins. However, in the myeloma system we were unable to detect any species of lipid which contained more than a single mannose residue or both mannose and $N$-acetylglucosamine residues, as might be expected if the core oligosaccharide were first constructed on a lipid backbone, prior to transfer to protein. But the low molecular' weight $(\sim 2200)$ compound containing mannose and phosphate, a major product formed when mannolipid is incubated with tumor microsomes, may be a degradation product of such a lipid. If this is the case, then the polyisoprenoid mannolipid described in this study may not be the only glycolipid intermediate involved in the transfer of mannose from GDP-mannose to protein.

\section{REFHRINCES}

1. Baynes, J. W., and Heath, H. C. (1972) Fed. Proc. 31, 437

2. Spiro, R. G. (1969) New Eng. J. Med. 281, 991

3. Kranmer, P. M. (1971) in Biomembranes (Manson, L. A., ed) Vol. 1, p. 67, Plenum Press, New York

4. Roskman, S. (1968) in Biochemistry of Glycoproteins and Related Substances: Cystic Fibrosis (Rossi, E., AND STAHL, E., eds) Part II, p. 244, S. Karger, New York

5. O'Brien, P. J., And Neufeld, E. F. (1972) in Glycoproteins (Gottschalk, A., ed) 2nd Ld., Part B, p. 1170, American Eilsevier Publishing Co., New York

6. Richard, M., Broquet, P., Got, R., and Louisot, P. (1971) Biochimie 53, 107

7. Richard, M., Broquet, P., and Louisot, P. (1972) J. Mol. Cell. Cardiol. 4, 465
8. Richuxds, J, B., and Hemming, F. W. (1972) Biochem. J. 130, 77

9. Mizchers, F. (1969) Biochemistry 8, 938

10. Mrichers, F., and Knopf, P. M. (1968) Cold Spring Harbor Symp. Quant. Biol. 32, 255

11. Chor, Y. S., Knor F, P. M., And Lennox, E. S. (1971) Biochemistry 10,668

12. Mrechers, F. (1970) Biochem. J. 119, 765

13. Rothfield, L., and Romeo, D. (1971) Bacteriol. Rev. 35, 14

14. Lenninz, W. J., and Scher, M. G. (1972) Biochim. Biophys. Acta 265, 417

15. Burgos, J., Hemming, F. W., Pennoci, J. F., And Morton,

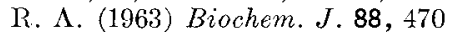

16. Behrens, N. H., and Limoir, I. F. (1970) Proc. Aat. Acad. Sci. U.S.A. 66, 153

17. Caccam, J. F., JaCKson, J. J., ind Hylar, E. H. (1969) Biochem. Biophys. Res. Commun. 35, 505

18. Lowry, O. H., Rosebrough, N. J., FARR, A. L., and R.inditi, R. J. (1951) J. Biol. Chem. 193, 265

19. Mrlier, G. L. (1959) Anal. Chem. 31, 964

20. Bartlett, G. R. (1959) J. Biol. Chem. 234, 466

21. Dittmeis, J. C., and Wrids, M. A. (1969) Methods Enzymol. 14, 486

22. Park, J. T., and Johnson, M. J. (1949) J. Biol. Chem. 181, 149 23. Rouser, G., Kritchevsky, (X., Helder, D., and Lifber, J. (1963) J. Amer. Oil Chem. Soc. 40, 425

24. Folch, J., Lien, M., and Slonne-Stanliy, G, H. (1957) J Biol. Chem. 226, 497

25. Werber, K., AND Kuter, D. J. (1971) J. Biol. Chem. 246, 4504

26. White, D. C., And Freliman, F. E. (1967) J. Bacteriol. 94, 1854

27. Dankert, M., Wright, A., Kelley, W. S., and Robbins, P. W. (1966) Arch. Biochem. Biophys. 116, 425

28. Trevelyan, W. E., Procter, D. P., and Harrison, J. S. (1950) Nature 166, 444

29. Luthis, M. (G., ANd Sheltawy, A. (1972) Biochem. J. 126, 251

30. Higashi, Y., Strominger, J. L., And Swbliley, C. J. (1967) Proc. Nat. Acad. Sci. U. S. A. 57, 1878

31. Troy, F. A., Frirman, F. Fi., and Heath, E. C. (1971) J. Biol. Chem. 246, 118

32. Brimrins, N. H., Parodi, A. J., Leloir, L. F., and Krigman, C. R. (1971) Arch. Biochem. Biophys. 143, 375

33. Scher, M., Lennarz, W. J., and Sweeley, C. J. (1968) Proc. Nat. Acad. Sci. U.S.A. 59, 1313

34. Bhatti, T., and Clamp, J. R. (1968) Biochim. Biophys. Acla 170,206

35. Makino, M., and Yamashina, I. (1966) J. Biochem. ('Tokyo) 60,262

36. Arma, T., ant Spiro, R. G. (1972) J. Biol. Chem. 247, 1836

37. Plummer, T. H., JR., And Hrrs, C. H. W. (1964) J. Biol. Chem. 239,2530

38. Tanner, W. (1969) Biochem. Binphys. Res. Commun. 35, 144

39. Sentandreu, R., and InMpen, J. O. (1972) Fed, Eur. Biochem. Soc. 27, 331

40. Mruchers, F., Leniox, Ji. S., anis Facon, M. (1966) Biochem. Biophys. Res. Commun. 24, 244

41. De Luch, L., Rosso, G., and Wolf, G. (1970) Biochem. Biophys. Res. Commun. 41, 615

42. Rodriguez, P., Bello, O., ani) Gaede, K. (1972) Fed. Eur. Biochem. Soc. Let. 28, 133

43. De LuCa, L., Mafestie, N., Rosso, (i., and Wolf, G. (1973) J. Biol. Chem. 248, 641

44. Johnson, H. V., Martinovic, J., and Johnson, B. C. (1971) Biochem. Biophys. Res. Commun. 43, 1040

45. Parodi, A. J., Brhrens, N. H., Leloir, L. F., ANd Carminatit, H. (1972) Proc. Nat. Acad. Sci. U. S. A. 69, 3268

46. Tetas, M., Chao, H., and Molnar, J. (1970) Arch. Biochem. Biophys. 138, 135

47. Molnar, J., Chao, H., and Ikehara, Y. (1971) Biochim. Biophys. Acta 239, 401

48. Mookrerjea, S., Cole, D. F. C., Chow, A., and letts, P. (1972) Can. J. Biochem. 50, 1094 